\title{
Improved Deep-Red Phosphorescence in Cyclometalated Iridium Complexes via Ancillary Ligand Modification
}

\author{
Evanta Kabir, Steven Sittel, Boi-Lien Nguyen, and Thomas S. Teets ${ }^{\star[a]}$
}

\begin{abstract}
In this work, we describe bis-cyclometalated iridium complexes with efficient deep-red luminescence. Two different cyclometalating $\left(C^{\wedge} N\right)$ ligands-1-phenylisoquinoline (piq) and 2-(2pyridyl)benzothiophene (btp)-are used with six strong $\pi$-donating ancillary ligands $\left(L^{\wedge} X\right)$ to furnish a suite of 10 new complexes with the general formula $\operatorname{Ir}\left(\mathrm{C}^{\wedge} N\right)_{2}\left(\mathrm{~L}^{\wedge} \mathrm{X}\right)$. Improvements in deep-red photoluminescence quantum yields were accomplished by the incorporation of sterically encumbering substituents onto the ancillary ligand, which can enhance the radiative rate constant $\left(k_{r}\right)$ and/or reduce the non-radiative rate constant $\left(k_{\mathrm{nr}}\right)$. Five of the complexes were characterized by X-ray crystallography, and all of them were investigated by in-depth spectroscopic and electrochemical measurements.
\end{abstract}

\section{Introduction}

Luminescent cyclometalated iridium(III) complexes have become one of the most prominent classes of molecular phosphors, contributing to numerous applications in photocatalysis, ${ }^{[1-3]}$ bioimaging, and sensing ${ }^{[4,5]}$ and most notably, organic lightemitting diodes (OLEDs) ${ }^{\left[{ }^{[-9]}\right.}$ and light-emitting electrochemical cells. ${ }^{[10,11]}$ These compounds luminesce from triplet excited states with ligand-centered $\left({ }^{3} \mathrm{LC}\right.$ or $\left.{ }^{3} \pi \pi^{*}\right)$ and metal-to-ligand charge transfer $\left({ }^{3} \mathrm{MLCT}\right.$ or $\left.{ }^{3} \mathrm{~d} \pi^{*}\right)$ character, mixing through configuration interaction. Homoleptic complexes of the type fac- $\operatorname{Ir}\left(C^{\wedge} N\right)_{3}\left(C^{\wedge} N=\right.$ cyclometalating ligand) are popular in both OLED and photocatalysis applications, ${ }^{[1,12,13]}$ and heteroleptic complexes of type $\operatorname{Ir}\left(C^{\wedge} N\right)_{2}\left(L^{\wedge} X\right)\left(L^{\wedge} X=\right.$ ancillary ligand $)$ have also become prominent. The ancillary ligands in the heteroleptic complexes can strongly influence the emission color, ${ }^{[14,15]}$ but most often shift redox potentials (especially the formally $\mid \mathrm{r}^{\mathrm{IV} /} / \mathrm{r}^{\mathrm{III}}$ couple) and perturb the excited state dynamics, while only subtly influencing the photoluminescence spectrum. ${ }^{[16,17]}$

Facile color tunability, highly photoluminescence quantum yields $\left(\Phi_{\mathrm{PL}}\right)$, and relatively short phosphorescence lifetimes ( $\left.\mathrm{T}\right)$ are some of the key features of cyclometalated iridium(III) complexes, which along with their good thermal and photostability lead to applications in diverse fields. There are many examples of iridium(III) complexes which emit in the blue to organge regions of the spectrum with near unity quantum yields, ${ }^{[18-22]}$ but red and near-infrared emitters in the lower-energy regions of the spectrum typically have lower quantum yields, which is an important performance metric to function in commercial devices. The

[a] Dr. E. Kabir, S. Sittel, B.-L. Nguyen, and Prof. Thomas S. Teets Department of Chemistry

University of Houston

Lamar Fleming Jr. Building, 3585 Cullen Blvd. Room 112

Houston, TX 77204-5003

E-mail: tteets@uh.edu

Supporting information for this article is given via a link at the end of the document quantum yield $\left(\Phi_{\mathrm{PL}}\right)$ is the ratio of the radiative rate constant $\left(k_{\mathrm{r}}\right)$ to the sum of radiative and non-radiative $\left(k_{\mathrm{nr}}\right)$ rate constants. According to the energy gap law, ${ }^{[23,24]}$ the non-radiative rate constant $\left(k_{n r}\right)$ increases for complexes with lower-energy excited states, on account of greater vibrational overlap between the ground and excited states. ${ }^{[25]}$ On the other hand, the radiative rate $\left(k_{\mathrm{r}}\right)$ has a cubic dependence on the transition energy and is expected to be smaller when longer emission wavelengths are accessed. ${ }^{[6]}$ The radiative rate constant $k_{\mathrm{r}}$ has a strong dependence on the spin-orbit coupling (SOC) in the excited state, which derives exclusively from the MLCT states that contribute to the emissive triplet state, $T_{1}$. The excited-state MLCT character is sensitive to the nature of the ancillary ligand in heteroleptic biscyclometalated iridium complexes, so synthetic strategies which augment the MLCT character can lead to increases in $k_{\mathrm{r}}$ and improvements in $\Phi_{\mathrm{PL}}$.

Using the above insights, our group has made significant advances in the performance of cyclometalated iridium complexes which emit in the low-energy regions of the visible spectrum. Our strategy involves the incorporation of nitrogendonor, electron-rich ancillary ligands into heteroleptic $\operatorname{Ir}\left(C^{\wedge} N\right)_{2}\left(L^{\wedge} X\right)$ complexes. We have shown that this strategy can lead to significant improvements in the photoluminescence quantum yields of yellow-orange ${ }^{[17]}$ and red-emitting ${ }^{[26]}$ compounds, with quantum yields as high as 0.8 for the red emitters. Subsequent work on related compounds revealed additional structure-property relationships in these red-emitting compounds, showing how the ancillary ligand structure (chelate ring-size, donor atoms, and substituents) influenced the nature of the excited state and the excited-state dynamics. ${ }^{[27]}$ One finding from these studies is that when the cyclometalated aryl group is a simple phenyl ring, as is the case for red-emitting compounds where $\mathrm{C}^{\wedge} \mathrm{N}=1$-phenylisoquinoline (piq), the photoluminescence wavelength is very sensitive to the electron-richness of the ancillary ligand, leading to deep-red luminescence (defined here as $\lambda_{\max }>650 \mathrm{~nm}$ ) for some ancillary ligands. For example, the complex $\operatorname{Ir}(\text { piq })_{2}($ dipba) $($ dipba $=\mathrm{N}, \mathrm{N}$-diisopropylbenzamidinate $)$ has a photoluminescence $\lambda_{\max }$ of $671 \mathrm{~nm}$ in room-temperature THF solution, with a respectable quantum yield of $0.34 .^{[26,27]}$ That said, the two deep-red emitters we prepared in these previous works had $k_{\mathrm{r}}$ values that were smaller and, particularly evident, $k_{\mathrm{nr}}$ values that were larger than the structurally related compounds that phosphoresce in the red region, limiting their quantum yields to fairly modest values. Further improvements in the quantum yields require synthetic strategies capable of augmenting the $k_{r}$ values and/or decreasing the $k_{\mathrm{nr}}$ values for compounds which emit in the deep red portion of the spectrum.

In this work we present synthetic modifications that lead to improved deep-red-emitting cyclometalated iridium complexes. Two key findings of this report are (i) sterically encumbering substituents on the electron-rich ancillary ligand can lead to significant improvements in $\Phi_{\mathrm{PL}}$ for deep-red phosphors, and (ii) making the ancillary ligand even more electron rich can shift the photoluminescence to the near-infrared (NIR) region, $\lambda_{\max }>700$ $\mathrm{nm}$. Our work here describes a suite of ten heteroleptic bis- 
cyclometalated iridium complexes, prepared by pairing the cyclometalating ligands piq and btp with six new ancillary ligands. This work provides further insight into the influence of the ancillary ligand structure on the electrochemical and photophysical properties, highlighting the effects of replacing $\mathrm{N}$-aryl substituents with alkyl groups, and of augmenting the steric profile of the ancillary ligand. Significantly, in a few of the compounds the modifications to the ancillary ligand lead to increases in $k_{\mathrm{r}}$ and/or decreases in $k_{n r}$ relative to structurally related compounds, producing deep-red emitters with photoluminescence quantum yields among the highest reported to date.

\section{Results and Discussion}

Synthesis of heteroleptic iridium complexes. The general synthetic procedure for the ten new complexes of type $\operatorname{Ir}\left(C^{\wedge} N\right)_{2}(L X) \quad\left(C^{\wedge} N=1\right.$-phenylisoquinoline (piq) and 2-(2pyridyl)benzothiophene (btp)) is described in Scheme 1. These two cyclometalating ligands are paired with six different electronrich ancillary ligands to prepare the new compounds described here, and Scheme 1 also summarizes three reference $\operatorname{Ir}(\mathrm{piq})_{2}\left(\mathrm{~L}^{\wedge} \mathrm{X}\right)$ compounds, $\mathbf{R} 1-\mathbf{R}$ 3, which will be frequently referred to in this paper. In previous research we have extensively worked with $N$-phenyl-substituted $\beta$-diketiminate $\left(\mathrm{NacNac}^{\mathrm{Me}}\right)$ and $\beta$ ketoiminate $\left(\mathrm{acNac}^{\mathrm{Me}}\right)$ ancillary ligands. ${ }^{[17,26,28,29]}$ To increase the steric profile we introduced methyl substituents at the ortho positions of the $\mathrm{N}$-aryl in (dmp) ${ }_{2} \mathrm{NacNac}^{\mathrm{Me}}$. Modifications to make the ancillary ligand more electron-rich include replacing backbone methyl groups with dimethylamino substituents ( $\mathrm{NacNac}^{\mathrm{NMe}}$ ), or replacing the $\mathrm{N}$-phenyl substitutents with cyclohexyl rings in $(\mathrm{Cy})_{2} \mathrm{NacNac}^{\mathrm{Me}}$ and (Cy)acNac ${ }^{\mathrm{Me}}$. Similarly, we ${ }^{[26,27]}$ and others ${ }^{[30-}$ ${ }^{32]}$ have used an amidinate ancillary ligand (dipba) in the design of bis-cyclometalated iridium complexes, and here we incoroporate modifications to make the amidinate more sterically encumbered (dipba ${ }^{\text {mes }}$ ), or make it more electron-rich by changing to a guanidinate ( dipg $^{\mathrm{NMe} 2}$ ). The numbering scheme uses numerical designators for each $\mathrm{C}^{\wedge} \mathrm{N}$ ligand ( $\mathrm{piq}=1$, and btp $=2$ ), with letters $(\mathbf{a}-\mathbf{f})$ denoting each $L^{\wedge} X$ ligand. To prepare the complexes, the chloro-bridged dimers $\left[\operatorname{Ir}\left(\mathrm{C}^{\wedge} N\right)_{2}(\mu-\mathrm{Cl})\right]_{2}$ were treated with $(\mathrm{dmp})_{2} \mathrm{NacNac}^{\mathrm{Me}} \mathrm{K}$ or $\mathrm{NacNac}^{\mathrm{NMe} 2} \mathrm{~K}$ at room temperature in THF to afford complexes $\mathbf{1} \mathbf{a}-\mathbf{b}$ and $\mathbf{2} \mathbf{a}-\mathbf{b}$ in moderate yields. A slightly different method was used to obtain complexes 1 $\mathbf{c}-\mathbf{d}$ and $\mathbf{2 c}-\mathbf{d}$, where the chloro-bridged dimers were treated with the in situ-generated lithium salt of dipbaMes and dipg $^{\mathrm{NMe} 2}$ in tetrahydrofuran (THF) at $85^{\circ} \mathrm{C}$, whereas for $1 \mathrm{e}-\mathrm{f}$ the piq-ligated dimer was treated with $(\mathrm{Cy})_{2} \mathrm{NacNac}^{\mathrm{Me}} \mathrm{K}$ or (Cy)acNac ${ }^{\mathrm{Me}} \mathrm{K}$ in toluene at $130{ }^{\circ} \mathrm{C}$. The identity and the bulk purity of the complexes were confirmed by ${ }^{1} \mathrm{H}$ and ${ }^{13} \mathrm{C}\left\{{ }^{1} \mathrm{H}\right\}$ NMR.

The NMR spectra evinced $C_{2}$ symmetry for all complexes except 1f, where asymmetric (Cy)acNac ancillary ligand results in a $C_{1}$ point group, giving rise to distinct NMR resonances for each proton and carbon nucleus. All NMR spectra show the presence

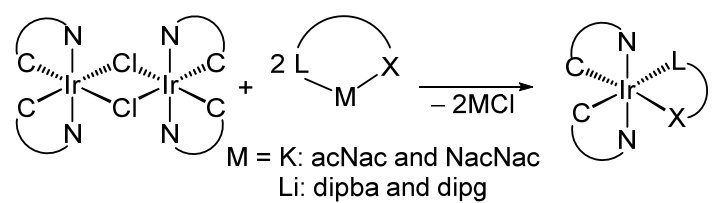

Li: dipba and dipg

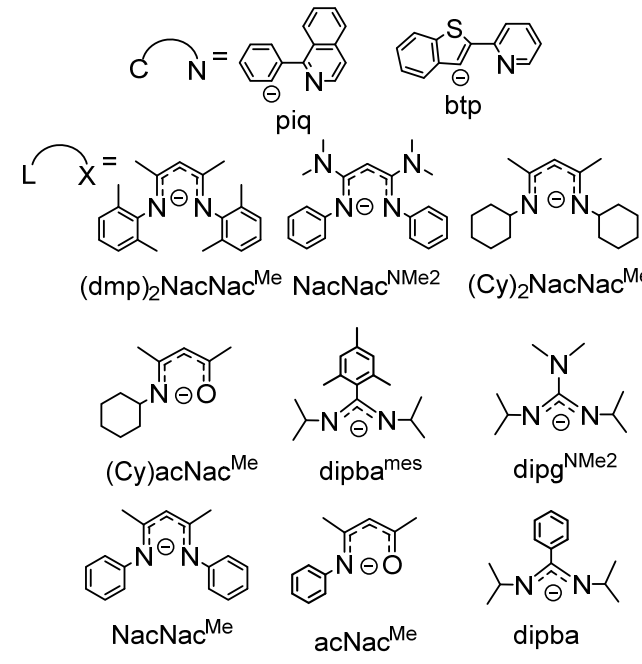

Compounds new to this work:

1a: $C^{\wedge} N=$ piq, $L^{\wedge} X=(d m p)_{2} \mathrm{NacNac}^{\mathrm{Me}}$

1b: $C^{\wedge} N=$ piq, $L^{\wedge} X=\mathrm{NaCNac}^{\mathrm{NMe} 2}$

1c: $C^{\wedge} N=$ piq, $L^{\wedge} X=$ dipba ${ }^{\text {mes }}$

1d: $C^{\wedge} N=$ piq, $L^{\wedge} X=\operatorname{dipg}^{\mathrm{NMe} 2}$

1e: $C^{\wedge} N=$ piq, $L^{\wedge} X=(C y)_{2} \mathrm{NacNac} M e$

1f: $C^{\wedge} N=$ piq, $L^{\wedge} X=(C y) \operatorname{acNac}^{M e}$

2a: $C^{\wedge} N=$ btp, $L^{\wedge} X=(\mathrm{dmp})_{2} \mathrm{NacNac} C^{\mathrm{Me}}$

2b: $C^{\wedge} N=$ btp, $L^{\wedge} X=\mathrm{NacNac}^{\mathrm{NMe} 2}$

2c: $C^{\wedge} N=$ btp, $L^{\wedge} X=$ dipbames

2d: $C^{\wedge} N=$ btp, $L^{\wedge} X=\operatorname{dipg}^{\mathrm{NMe} 2}$

Reference compounds:

R1: $C^{\wedge} N=$ piq, $L^{\wedge} X=\mathrm{NacNac}^{\mathrm{Me}}$

R2: $C^{\wedge} N=$ piq, $L^{\wedge} X=\operatorname{acNac}^{\mathrm{Me}}$

R3: $C^{\wedge} N=$ piq, $L^{\wedge} X=$ dipba

Scheme 1. Synthesis of bis-cyclometalated iridium complexes.

of single product in each case, confirming the absence of any isomeric complexes in the isolated products.

Structural characterization by X-ray crystallography. Complexes $\mathbf{1 c}, \mathbf{1 d}, \mathbf{2 a}, \mathbf{2 b}$, and $\mathbf{2 d}$ were characterized by single crystal X-ray diffraction, with the structures depicted in Figures 1 and S1, and detailed crystallographic data are reported in Tables $\mathrm{S} 1-\mathrm{S} 2$. Single crystals were grown via vapor diffusion of pentane into dichloromethane or tetrahydrofuran solution or by layering pentane onto a dichloromethane solution at room temperature inside the glovebox. The iridium center is found to be at the center of a distorted octahedral geometry in all of the characterized structures and the expected trans disposition of the two nitrogen atoms of the cyclometalating ligands is observed. Excepting 


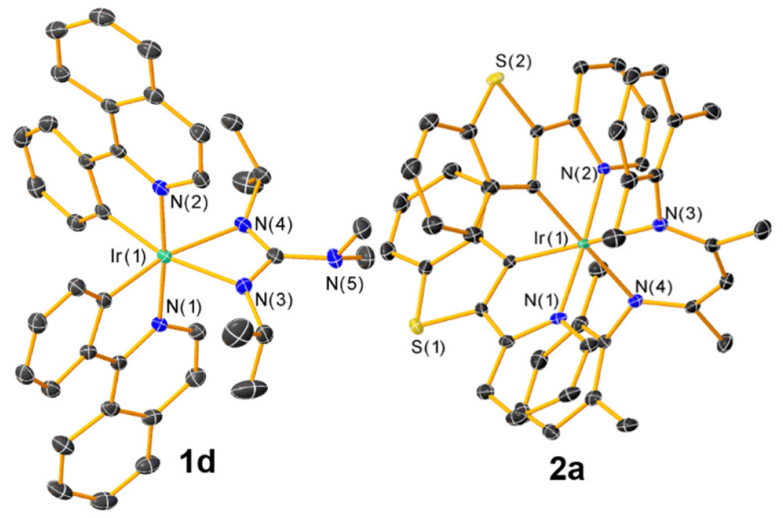

Figure 1. Molecular structures of complexes $1 \mathrm{~d}$ and $\mathbf{2 a}$, determined by singlecrystal X-ray diffraction. Ellipsoids are depicted at $50 \%$ probability with hydrogen atoms and solvent molecules.

$\mathrm{NacNac}^{\mathrm{NMe} 2}$ complex $\mathbf{2 b}$, where the NacNac core is "buckled" in a fashion analogous to other structurally characterized $\mathrm{NacNac}^{\mathrm{NM} 2}$ complexes from our group, ${ }^{[28,29]}$ the ancillary ligand core and the chelated iridium atom are planar. The $\mathrm{C}-\mathrm{O}, \mathrm{C}-\mathrm{N}$, and $\mathrm{C}-\mathrm{C}$ bond distances of the ancillary ligand chelate rings in all five characterized complexes are intermediate between typical single- and double-bond distances, suggesting a m-delocalized core. Unsurprisingly, the structure of the ancillary ligand determines the ancillary ligand $\mathrm{N}-\mathrm{C}-\mathrm{N}$ bite angle, which averages $60.49(10)^{\circ}$ for complexes $\mathbf{1 c}, \mathbf{1 d}$, and $\mathbf{2 d}$, and is much larger in NacNac complexes $\mathbf{2 b}$ is $\left(85.26(7)^{\circ}\right)$ and $\mathbf{2 a}\left(90.27(10)^{\circ}\right)$.

The synthetic modifications we have made in this work, in an effort to make the ancillary ligands more sterically encumbered and/or more electron-rich, generally had only subtle effects on solid-state structural metrics. For example, $(\mathrm{dmp})_{2} \mathrm{NacNac}{ }^{\mathrm{Me}}$ complex 2a shows a close approach of both $\mathrm{N}$-aryl groups to a nearby Ir-aryl, in a nearly eclipsed orientation with apparent $\pi-\pi$ stacking between the rings. This type of structural motif was also observed in several other iridium NacNac complexes previously described by our group, which lacked the ortho-methyl substituents. ${ }^{[17,33]}$ In addition, comparison of previously reported $\operatorname{Ir}(\mathrm{btp})_{2}(\mathrm{dipba})^{[26]}$ with complex 1c shows that increased steric bulk on the amidinate's central aryl ring exerts only subtle influences on the structure. One small difference between these structures is an increase in the dihedral angle between the backbone aryl ring and the mean plane of the four-member chelate ring, which increases from $70.75^{\circ}$ in the dipba complex to $81.58^{\circ}$ in the mesityl-substituted complex 1c. Similarly, the addition of electrondonating groups in dipg $^{\mathrm{NMe} 2}$ complexes $\mathbf{1 d}$ and $\mathbf{2} \mathbf{d}$ does not demonstrably perturb the structures relative to the analogous amidinate complexes.

Electrochemical Properties. Figures 2 and S2 display overlaid cyclic voltammograms of the complexes, arranged by $\mathrm{C}^{\wedge} \mathrm{N}$ ligands, and their results are summarized in Table 1. Redox potentials are reported relative to the ferrocenium/ferrocene couple. All the

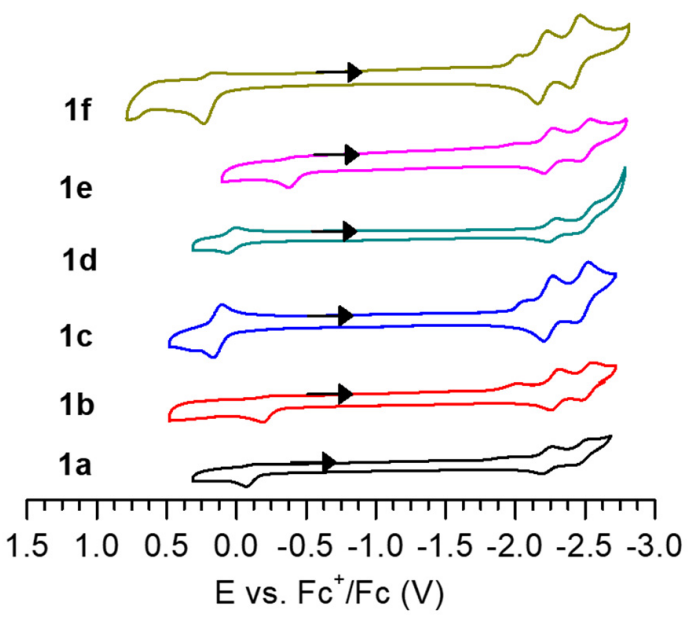

Figure 2. Overlaid cyclic voltammograms of complexes $\mathbf{1 a}-\mathbf{f}$. CVs were recorded in acetonitrile with $0.1 \mathrm{M} \mathrm{NBu}_{4} \mathrm{PF}_{6}$ supporting electrolyte, using a glassy carbon working electrode and a scan rate of $0.1 \mathrm{~V} / \mathrm{s}$. The arrows indicate the scan direction. Concentrations were not carefully controlled, and currents are low in some of plots because of the limited solubility of some of the compounds in acetonitrile.

complexes described in this work display a formally $\mathrm{Ir}^{\mathrm{IV}} / \mathrm{/r} \mathrm{r}^{\mathrm{III}}$ redox couple $\left(E^{\mathrm{ox}}\right)$, with potentials that are strongly dependent on the identity of the ancillary ligand. Complexes supported by $(\mathrm{dmp})_{2} \mathrm{NacNac}^{\mathrm{Me}}, \mathbf{1 a}$ and $\mathbf{2 a}$, have similar oxidation potentials $\left(E^{\mathrm{ox}}\right.$ $=-0.07 \mathrm{~V}$ and $+0.06 \mathrm{~V}$, respectively), close to the ferrocenium/ferrocene couple. The electron-donating backbone dimethylamino groups in complexes $\mathbf{1 b}$ and $\mathbf{2 b}$ make the molecules easier to oxidize, with potentials that are cathodically shifted by at least $120 \mathrm{mV}$. Addition of dimethylamino substituents in dipg ${ }^{\mathrm{NM} 2}$ complexes $\mathbf{1 d}$ and $\mathbf{2} \mathbf{d}$ resulted in a cathodic shift of $110 \mathrm{mV}$ when comparing to the amidinate complexes $\mathbf{1 c}$ and $\mathbf{2 c}$. The largest effect on the redox potential was realized by replacing the $\mathrm{NacNac} N$-aryl groups with the cyclohexyl groups, resulting in an oxidation potential for complex $1 \mathrm{e}$ of $-0.37 \mathrm{~V}$. This observation is in line with a previously reported (Cy) ${ }_{2} \mathrm{NacNac}$ complex from our group, $\operatorname{Ir}(\mathrm{ppy})_{2}\left((\mathrm{Cy})_{2} \mathrm{NacNac}\right)$ (ppy = 2-phenylpyridine), which had a nearly identical value for $E^{\mathrm{ox}}$ and shows that the basicity of the chelated nitrogen atoms can strongly influence the HOMO energy. Another clear trend, which we have previously noted in other related complexes, ${ }^{[26,27]}$ is that compounds with the smaller $\mathrm{N}-\mathrm{C}-\mathrm{N}$ bite angle, $\mathbf{1} \mathbf{c} / \mathbf{d}$ and $\mathbf{2 c / d}$, were more difficult to oxidize than the NacNac complexes. Finally, complex $1 f\left(E^{o x}=+0.24 \mathrm{~V}\right)$ with a mixed $N, O(\mathrm{Cy}) \mathrm{acNac}^{\mathrm{Me}}$ chelate, was the most difficult to oxidize of the complexes in the piq series, and the reported potential is quite similar to the previously reported $\mathrm{N}$-phenyl substituted complex $\operatorname{Ir}(\text { piq })_{2}\left(\right.$ acNac $\left.^{\mathrm{Me}}\right)(\mathbf{R} 2){ }^{[26]}$ suggesting that for the acNac ancillary ligand the basicity of the nitrogen donor is less important in determining $\mathrm{HOMO}$ energies and associated redox potentials than it is in the NacNac series. To summarize, the trends in $E^{o x}$ values indicate that the energy of the HOMO is 
strongly determined by the nature of the ancillary ligand, with associated redox potentials that span a wide range of $>0.5 \mathrm{~V}$.

Table 1. Summary of cyclic voltammetry data for $\operatorname{Ir}(\mathrm{piq})_{2}\left(\mathrm{~L}^{\wedge} \mathrm{X}\right)$ complexes 1a-f

\begin{tabular}{|c|c|c|}
\hline \multirow[b]{2}{*}{$\mathrm{C}^{\wedge} \mathrm{N}=$ piq (1) } & \multicolumn{2}{|c|}{$\left(E\right.$ vs. $\left.\mathrm{Fc}^{+} / \mathrm{Fc}\right) / \mathrm{V}^{[a]}$} \\
\hline & $E^{\mathrm{red}}$ & $E^{\text {ox }}$ \\
\hline $\mathrm{L}^{\wedge} \mathrm{X}=(\mathrm{dmp})_{2} \mathrm{NacNac}^{\mathrm{Me}}$ (1a) & $-2.22,-2.48$ & $-0.07^{[b]}$ \\
\hline$L^{\wedge} X=\operatorname{NacNac}^{\mathrm{Me} 2}$ (1) $\left.\mathbf{b}\right)$ & $-2.28-2.52$ & $-0.19^{[b]}$ \\
\hline$L^{\wedge} X=\operatorname{dipba}^{\text {Mes }}(\mathbf{1 c})$ & $-2.24,-2.48$ & +0.14 \\
\hline$L^{\wedge} X=\operatorname{dipg}^{\mathrm{NMe} 2}(\mathbf{1 d})$ & $-2.26,-2.59^{[b]}$ & +0.03 \\
\hline$L^{\wedge} X=(C y)_{2} \mathrm{NacNac}^{\mathrm{Me}}(\mathbf{1 e})$ & $-2.24,-2.50$ & $-0.37^{[b]}$ \\
\hline$L^{\wedge} X=(C y) \operatorname{acNac}^{\mathrm{Me}}$ (1f) & $-2.20,-2.42$ & $+0.24^{[b]}$ \\
\hline \multicolumn{3}{|l|}{$\mathrm{C}^{\wedge} \mathrm{N}=\operatorname{btp}(\mathbf{2})$} \\
\hline$L^{\wedge} X=(\mathrm{dmp})_{2} \mathrm{NacNac}^{\mathrm{Me}}(\mathbf{2 a})$ & $-2.58^{[b]}$ & $0.06^{[b]}$ \\
\hline$L^{\wedge} X=\operatorname{NacNac}^{\mathrm{Me} 2}$ (2b) & $-2.62^{[b]}$ & -0.17 \\
\hline$L^{\wedge} X=\operatorname{dipba}^{\text {Mes }}(\mathbf{2 c})$ & $-2.57^{[b]}$ & 0.23 \\
\hline $\mathrm{L}^{\wedge} \mathrm{X}=\operatorname{dipg}^{\mathrm{NMe2}} \mathbf{( 2 d )}$ & $-2.60^{[b]}$ & 0.12 \\
\hline
\end{tabular}

[a] Experiments were performed in acetonitrile solvent with $0.1 \mathrm{M}$ $\mathrm{NBu}_{4} \mathrm{PF}_{6}$ electrolyte with scan rate of $0.1 \mathrm{~V} / \mathrm{s}$ using a glassy carbon working electrode and a silver wire pseudo-reference electrode. Potentials are referenced against the ferrocene/ferrocenium redox couple. [b] Observed wave is irreversible, and the respective $E_{p, c}$ or $E_{p, a}$ peak potential is reported. one clearly-resolved reduction wave at a more negative potential than the piq series. In contrast to the HOMO energies, which are very dependent on the structure of the ancillary ligand, the observed reduction potentials of the new complexes indicate minimal perturbation of the $\mathrm{C}^{\wedge} \mathrm{N}$-centered LUMO energies across the series.

Photophysical Properties. The UV-vis absorption spectra and steady-state and time-resolved emission spectra of all the complexes were recorded in THF at room temperature. The overlaid UV-vis absorption spectra of complexes are depicted in Figure S4. UV-vis absorption features and assignments are very similar to other bis-cyclometalated iridium complexes from our group with the same $\mathrm{C}^{\wedge} \mathrm{N}$ ligands, ${ }^{[26,27]}$ with intense absorption bands in the UV region assigned to spin-allowed ligand-centered $\Pi \rightarrow \Pi^{*}$ transitions ( $\left.{ }^{1} \mathrm{LC}\right)$ involving cyclometalating and ancillary ligands, and less intense, overlapping absorption bands tailing beyond $500 \mathrm{~nm}$ for btp (2a-d) and $600 \mathrm{~nm}$ for piq (1a-f) complexes assigned as both singlet and triplet metal-to-ligand charge transfer $\left({ }^{1} \mathrm{MLCT} /{ }^{3} \mathrm{MLCT}\right)$ transitions.

All of the complexes described here are luminescent at room temperature in deareated THF solutions. Table 2 summarizes the steady-state and time-resolved emission data, Figures 3 and 4 show overlaid room temperature emission spectra of 1 and $\mathbf{2}$, and the emission spectra at $77 \mathrm{~K}$ are displayed in Figures S15-S24. The excitation spectra of the new complexes were also collected and shown in Figures S5-S14, and in each case are superimposed with the absorption spectrum, indicating that luminescence arises solely from the iridium complex.

Our primary goal in this work is to produce complexes with improved deep-red photoluminescence attributes. The observed room-temperature emission for all of the complexes with $C^{\wedge} N=$ piq occurs in the deep red portion of the spectrum, with maxima

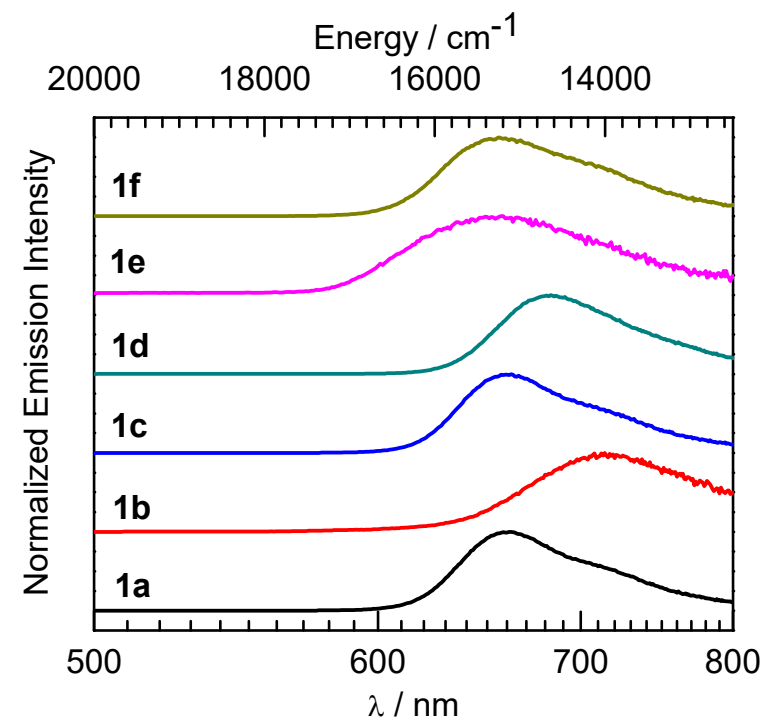

Figure 3. Overlaid emission spectra of complexes $1 a-f$, were recorded in THF at room temperature. Samples were excited at $\lambda_{\mathrm{ex}}=420 \mathrm{~nm}$.
The reduction potentials $\left(E^{\text {red }}\right)$ of the new complexes described here depend only slightly on the identity of the $L^{\wedge} X$ ligands. The two observed waves for the piq complexes are associated with sequential population of a $\pi^{*}$ orbital on each $C^{\wedge} \mathrm{N}$ ligand, with measured potentials beyond $-2.0 \mathrm{~V}$. We do note a minor "pre-feature" wave near $-2.0 \mathrm{~V}$ in most complexes, which arises irrespective of scan direction and we think can be attributed to the poor solubility in acetonitrile upon reduction, causing some deposition onto the electrode. As such the reported $E^{\text {red }}$ values are for the one or two clearly-resolved waves that occur beyond this minor pre-feature. Consistent with this notion, this pre-feature wave was mostly absent when the CVs of complexes 1a-1c were recorded in THF, as shown in Figure S3 of the Supporting Information. The first reduction potentials for all piq-ligated complexes were reversible, ranging from $-2.20 \mathrm{~V}$ to $-2.28 \mathrm{~V}$. Another subsequent reduction wave was observed for complexes 1a-f, with potentials ranging between -2.42 (1f) and -2.59 (1d) $\mathrm{V}$, reversible in most cases. All btp-ligated complexes display only 
Table 2. Summary of photoluminescence data for all complexes

\begin{tabular}{|c|c|c|c|c|c|c|}
\hline & \multicolumn{3}{|c|}{$\lambda_{\max } / \mathrm{nm}^{[\mathrm{a}]}$} & \multirow[b]{2}{*}{$\Phi_{\mathrm{PL}}$} & \multirow[b]{2}{*}{$\mathrm{T} / \mu \mathrm{S}$} & \multirow[b]{2}{*}{$k_{r}^{[c]} \times 10^{-5} / \mathrm{s}^{-1} / k_{n r}^{[c]} \times 10^{-5} / \mathrm{s}^{-}$} \\
\hline & $\begin{array}{l}\text { THF at } \\
293 \mathrm{~K}\end{array}$ & $\begin{array}{l}\text { Toluene at } \\
293 \mathrm{~K}\end{array}$ & $\begin{array}{l}\text { Toluene at } \\
77 \mathrm{~K}\end{array}$ & & & \\
\hline 1a & 660 & 655 & 642,697 & 0.53 & 0.81 & $6.5 / 5.8$ \\
\hline $1 \mathrm{~b}$ & 707 & 701 & 666 & 0.071 & $0.90^{[b]}$ & $0.78 / 10$ \\
\hline 1c & 661 & 656 & 640,699 & 0.58 & 0.74 & $7.8 / 5.6$ \\
\hline 1d & 683 & 683 & 620,678 & 0.37 & 0.53 & $6.8 / 11.8$ \\
\hline 1e & 658 & 658 & 640 & 0.022 & $0.74^{[\mathrm{b}]}$ & $0.30 / 13$ \\
\hline $1 f$ & 657 & 655 & 634,687 & 0.49 & 0.78 & $6.2 / 6.6$ \\
\hline $2 a$ & 624 & 622 & 605,664 & 0.27 & 4.0 & $0.68 / 1.8$ \\
\hline $2 b$ & 633 & 627 & 614,668 & 0.18 & 2.8 & $0.63 / 2.9$ \\
\hline $2 c$ & 619,668 & 619,665 & 609,667 & 0.31 & $3.9^{[b]}$ & $0.80 / 1.8$ \\
\hline $2 d$ & 626 & 626 & 611,671 & 0.30 & 3.1 & $0.98 / 2.3$ \\
\hline
\end{tabular}

[a] $\lambda_{\text {exc }}=420 \mathrm{~nm}$. [b] Bi-exponential. Reported lifetime is a weighted average of the two time constants. [c] $k_{\mathrm{r}}=\Phi / \mathrm{T}$ and $k_{\mathrm{nr}}=(1-\Phi) / \mathrm{T}$

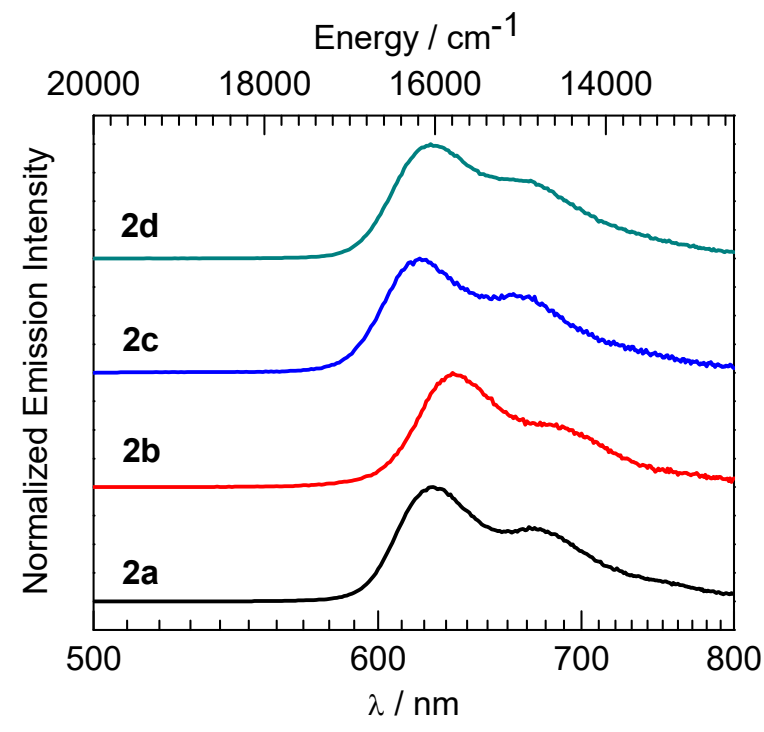

Figure 4. Overlaid emission spectra of complexes $2 a-d$, were recorded in THF at room temperature. Samples were excited at $\lambda_{\mathrm{ex}}=420 \mathrm{~nm}$. beyond $650 \mathrm{~nm}$ that are strongly dependent on the ancillary ligand. Two key observations are noted by examining the photoluminescence data of the piq series. First, we observe that making the ancillary ligand more electron-rich red-shifts the photoluminescence, offering a potential strategy for preparing near-infrared phosphors. In piq complexes there is substantial $\mathrm{HOMO} \rightarrow$ LUMO character in the emissive $\mathrm{T}_{1}$ state, and CV experiments (see above) show that the HOMO energies are significantly destabilized in the more electron-rich analogues. As a result, complexes with more electron-rich ancillary ligands have smaller HOMO-LUMO gaps and red-shifted photoluminescence. For example, the previously reported complex $\operatorname{Ir}(\mathrm{piq})_{2}\left(\mathrm{NacNac}^{\mathrm{Me}}\right)$ (R1) ${ }^{[26]}$ has a photoluminescence $\lambda_{\max }$ of $678 \mathrm{~nm}$, which shifts by $29 \mathrm{~nm}\left(605 \mathrm{~cm}^{-1}\right)$ to $707 \mathrm{~nm}$, in dimethylamino-substituted $\mathbf{1 b}$. Complex $1 \mathrm{~b}$ is the only compound in the series that is truly in the NIR region $\left(\lambda_{\max }>700 \mathrm{~nm}\right)$, but its modest photoluminescence quantum yield of 0.071 suggests that increasing the electronrichness of the ancillary ligand, while effective at producing NIR luminescence, may not be the best strategy for optimizing the quantum yield. Along the same lines, the complex $\operatorname{lr}(\text { piq })_{2}\left(\right.$ dipba $\left.^{\text {Mes }}\right)$ (1c) has a photoluminescence $\lambda_{\max }$ of $661 \mathrm{~nm}$, which bathochromically shifts by $22 \mathrm{~nm}\left(487 \mathrm{~cm}^{-1}\right)$ in the more electron-rich dipg ${ }^{\mathrm{NMe} 2}$ analogue $\mathbf{1 d}$.

The more significant outcome of this study is that certain structural modifications to the ancillary ligand can lead to larger $\Phi_{\mathrm{PL}}$ values for the deep-red emitting $\operatorname{Ir}(\mathrm{piq})_{2}\left(\mathrm{~L}^{\wedge} \mathrm{X}\right)$ complexes, 
producing some of the most efficient deep-red emitters ever reported. In studying the deep-red phosphorescent compounds R1 and R3, we noted modest photoluminescence quantum efficiencies on account of rather large $k_{\mathrm{nr}}$ values, as predicted by the energy-gap law. Our hypothesis leading into this work was that rigidifying the ancillary ligand, by adding sterically encumbering substituents, could lead to a suppression of $k_{\mathrm{nr}}$ and an increase in $\Phi_{\mathrm{PL}}$. This hypothesis was examined by preparing compounds $\mathbf{1 a}$ and $\mathbf{1 c}$, more sterically crowded analogues of $\mathbf{R} \mathbf{1}$ and R3. $\mathrm{NaCNac}^{\mathrm{Me}}$ compound R1 has a photoluminescence $\lambda_{\max }$ of $678 \mathrm{~nm}$ and a $\Phi_{\mathrm{PL}}$ of 0.17 , and in 1a we observe a blue-shift to $660 \mathrm{~nm}$, but a significant increase in quantum yield to 0.53 . Similarly, dipba compound R3 emits at $671 \mathrm{~nm}$ with a quantum yield of 0.34 , and in 1c the photoluminescence is mildly blueshifted to $661 \mathrm{~nm}$ but the quantum yield is much higher at 0.58 . The increases in quantum yield are to some extent a result of a decrease in $k_{\mathrm{nr}}$, with a ca. $40 \%$ reduction in each case, but unexpectedly the more structurally rigid analogues $1 \mathrm{a}$ and $1 \mathrm{c}$ also exhibited larger radiative rate constants $\left(k_{r}\right)$, which increased by a factor of 3.1 (R1 to $1 \mathrm{a}$ ) and 1.7 (R3 to 1c). Thus, both an increase in $k_{\mathrm{r}}$ and a decrease in $k_{\mathrm{nr}}$ led to the higher quantum yields observed in sterically encumbered complexes $\mathbf{1 a}$ and $\mathbf{1 c}$. We hypothesize that the slight blue-shift in complexes $1 \mathrm{a}$ and $\mathbf{1 c}$, relative to $\mathbf{R} \mathbf{1}$ and $\mathbf{R} \mathbf{3}$, is a result of the more sterically crowded ancillary ligand leading to a less distorted $T_{1}$ state, reducing the singlet-triplet gap. We also discovered, by preparing (Cy)acNac ${ }^{\mathrm{Me}}$ complex 1f, that incorporation of $\mathrm{N}$-alkyl substituents onto a $\beta$ ketoiminate can also be an effective strategy for deep-red luminescence, with complex $1 \mathrm{f}$ exhibiting a $\lambda_{\max }$ of $657 \mathrm{~nm}$ and a quantum yield of 0.49 .

Taken together, these results not only unveiled several structure-property relationships, but also led to the discovery of a few top-performing deep-red phosphors that are significantly more efficient than previous analogues prepared by our group. We have three new compounds, 1a, 1c, and 1f where the photoluminescence maximum is beyond $650 \mathrm{~nm}$ and the quantum yield is 0.49 or greater, and a fourth compound, $\mathbf{1 d}$, where the luminescence is very deep in the red $\left(\lambda_{\max }=683 \mathrm{~nm}\right)$ and the quantum yield is still a respectable value, 0.37 . These compounds all have higher quantum yields than some of the best-known deep-red phosphorescent iridium compounds in the literature. For example, $\operatorname{Ir}\left(\mathrm{C}^{\wedge} \mathrm{N}\right)_{2}$ (acac) (acac = acetylacetonate) compounds where $\mathrm{C}^{\wedge} \mathrm{N}$ is an 8-phenylquinoline derivative, an isomer of piq, luminesce in the deep red $\left(\lambda_{\max }=650-680 \mathrm{~nm}\right)$ but with a maximum $\Phi_{\mathrm{PL}}$ of $0.11 .^{[34]}$ In addition, a picolinate supported biscyclometalated iridium complex with $\mathrm{C}^{\wedge} \mathrm{N}=6$ phenylphenanthridine, a m-extended analogue of piq, luminesces with $\lambda_{\max }=648 \mathrm{~nm}$ and $\Phi_{\mathrm{PL}}=0.27 .{ }^{[35]}$ Some recent improvements have been made by introducing new $C^{\wedge} N$ ligands, sticking exclusively with acac or picolinate-supported bis-cyclometalated iridium structures. These include an $\operatorname{Ir}\left(\mathrm{C}^{\wedge} \mathrm{N}\right)_{2}(\mathrm{acac})$ complex with phenazine-derived $\mathrm{C}^{\wedge} \mathrm{N}$ ligands $\left(\lambda_{\max }=684 \mathrm{~nm}\right.$ and $\left.\Phi_{\mathrm{PL}}=0.27\right),{ }^{[36]}$ an $\operatorname{Ir}\left(\mathrm{C}^{\wedge} \mathrm{N}\right)_{2}(\mathrm{acac}) \quad$ compound with spirofluorenedibenzosuberene[d]quinoxaline $\mathrm{C}^{\wedge} \mathrm{N}$ ligands $\left(\lambda_{\max }=686 \mathrm{~nm}\right.$ and $\left.\Phi_{\mathrm{PL}}=0.51\right)$, and finally two picolinate-supported complexes with benzo[b]thiophen-2-yl)quinoline $\mathrm{C}^{\wedge} \mathrm{N}$ ligands, $\pi$-extended versions of btp $\left(\lambda_{\max }=651\right.$ and $661 \mathrm{~nm}$, and $\Phi_{\mathrm{PL}}=0.48$ and 0.37 , respectively). ${ }^{[37]}$ Clearly, there has been a surge of interest in preparing efficient deep-red iridium phosphors and applying them in optoelectronic devices, and the compounds described here offer a complementary approach to accessing deep-red emitters and have photoluminescence attributes that rival or exceed these recent breakthrough examples.

As part of this study we prepared four compounds with $\mathrm{C}^{\wedge} \mathrm{N}=$ btp, another cyclometalating ligand known to engender red phosphorescence. In most cases, our previous work with $\operatorname{Ir}(\mathrm{btp})_{2}\left(\mathrm{~L}^{\wedge} \mathrm{X}\right)$ compounds showed that in these compounds the photoluminescence wavelength and excited-state dynamics were not responsive to the structure of the ancillary ligand. ${ }^{[26,27]} \mathrm{A}$ notable exception is the compound $\operatorname{Ir}(\text { btp })_{2}$ (dipba), which has a slightly redder photoluminescence $\left(\lambda_{\max }=622 \mathrm{~nm}\right)$ and much higher quantum yield $(0.79)$ than most other $\operatorname{Ir}(b t p)_{2}\left(L^{\wedge} X\right)$ compounds, but in almost every other case the emission wavelength was $\sim 610 \mathrm{~nm}$ and the quantum yield in the narrow range of $0.2-0.3$. We prepared compounds $\mathbf{2} \mathbf{a}-\mathbf{2} \mathbf{d}$ to examine whether ancillary ligands which are even more sterically encumbered or even more electron rich could influence the photoluminescence in a meaningful way. But as the data in Figure 4 and Table 2 show, the photoluminescence attributes of complexes $\mathbf{2 a - 2 d}$ are all quite similar. We do see a modest redshift of the photoluminescence in these compounds, by 7-21 nm $\left(185-542 \mathrm{~cm}^{-1}\right)$ relative to $\operatorname{Ir}(\mathrm{btp})_{2}(\mathrm{acac}),{ }^{[7]}$ but in no case is there an increase in quantum yield. We believe this difference in behavior between piq and btp complexes arises from the larger singlet-triplet gap in the latter's $C^{\wedge} N$ ligand-centered state, leading to less excited-state MLCT character and thus less influence of the electron-rich ancillary ligand. Acknowledging that the excitedstate dynamics of compounds with $C^{\wedge} N=$ btp are more difficult to influence, we believe going forward that a better strategy for continued development of deep-red and NIR emitters will be to use $\mathrm{C}^{\wedge} \mathrm{N}$ ligands akin to piq, where the cyclometalated aryl ring is a phenyl group and the ancillary ligand is expected to have a much more profound influence on the spectral profile and photoluminescence kinetics.

Further insight into the photoluminescence comes from lowtemperature $(77 \mathrm{~K})$ emission spectra of the complexes. Complexes with $\mathrm{C}^{\wedge} \mathrm{N}=$ piq, $\mathbf{1 a - f}$, have poorly resolved vibronic structure at room temperature, but in most cases, excepting the electron-rich NacNac complexes $\mathbf{1 b}$ and $\mathbf{1 e}$, two distinct vibronic maxima can be resolved at $77 \mathrm{~K}$ in toluene glass (Figures $\mathrm{S} 15$ $\mathrm{S} 20)$. The vibronic spacing for this series of compounds falls in the range of ca. $1216-1379 \mathrm{~cm}^{-1}$. Also evident in the piq series is a large rigidochromic blue-shift, which we ${ }^{[17,26,27]}$ and many others ${ }^{[38]}$ have previously noted is evidence for significant chargetransfer character in the emissive $T_{1}$ state. Better-resolved emission spectra were observed for btp complexes at $77 \mathrm{~K}$, with smaller rigidochromic shifts averaging $15 \mathrm{~nm}$ (ca. $400 \mathrm{~cm}^{-1}$ ) (Table 2 and Figures S21-S24). The vibronic spacing in the btp complexes is larger in most cases, at parity of ancillary ligand, and falls in the range of ca. $1316-1468 \mathrm{~cm}^{-1}$.

\section{Conclusions}


We have presented here a thorough study of the effect of ancillary ligand modification on the electrochemical and optical properties of bis-cyclometalated iridium complexes, focusing in particular on the effects of electron-donating and sterically encumbering substituents. Our primary goal in this work was to improve the quantum yields of deep-red emitting complexes. Appropriate electronic tuning of the ancillary ligand in $\operatorname{Ir}(\mathrm{piq})_{2}\left(\mathrm{~L}^{\wedge} \mathrm{X}\right)$ complexes begets luminesce in the deep-red region $\left(\lambda_{\max }>650 \mathrm{~nm}\right)$, and increasing the steric profile of the ancillary ligand can produce photoluminescence quantum yields $>0.5$, among the highest for deep-red phosphorescence. With the most extremely electronrich ancillary ligand $\mathrm{NacNac}^{\mathrm{NMe} 2}$ the photoluminescence is perturbed all the way to NIR region $\left(\lambda_{\max }>700 \mathrm{~nm}\right)$, although the quantum yield is modest. A smaller series of compounds with $\mathrm{C}^{\wedge} \mathrm{N}$ = btp were also prepared, but in these cases the photoluminescence wavelength and the excited-state dynamics are minimally sensitive to the structure of the ancillary ligand, and only red-emitting compounds with modest quantum yields $(\sim 0.2-$ $0.3)$ were produced. Taken together, these results show that our strategy of using electron-rich ancillary ligands is successful at producing some of the best-performing deep-red emitters available. Our future goals are to apply the strategy described here to significantly improve quantum yields for NIR emitters, in particular in compounds with phenyl-bound $\mathrm{C}^{\wedge} \mathrm{N}$ ligands where the excited-state dynamics are expected to be particularly sensitive to the ancillary ligand structure.

\section{Experimental Section}

Materials: Starting materials and reagents were of commercial origin and used without further purification. All reactions were executed in a nitrogenfilled glovebox operating at $<1 \mathrm{ppm}$ of $\mathrm{O}_{2}$ and $\mathrm{H}_{2} \mathrm{O}$. Anhydrous solvents for reactions and optical measurements were dried by the method of Grubbs, ${ }^{[39]}$ passing through dual alumina columns on a commercial solvent purification system (SPS), and stored over $3 \AA$ molecular sieves. All NMR solvents were dried and stored over $3 \AA$ molecular sieves in the glovebox; $\mathrm{CDCl}_{3}$ was also stored over potassium carbonate in addition to sieves. Cyclometalated iridium dimers $\quad\left[\operatorname{Ir}\left(\mathrm{C}^{\wedge} N\right)_{2}(\mu-\mathrm{Cl})\right]_{2} \quad\left(\mathrm{C}^{\wedge} \mathrm{N}=1-\right.$ phenylisoquinoline (piq) and 2-(2-pyridyl)benzothiophene (btp)) were prepared by the method of Nonoyama, ${ }^{[40]}$ refluxing $\mathrm{IrCl}_{3} \cdot \mathrm{nH}_{2} \mathrm{O}$ with $2-2.3$ equiv of the cyclometalating ligand in a 3:1 mixture of 2-ethoxyethanol and water. The ligand $(\mathrm{Cy})_{2} \mathrm{NacNac}{ }^{\mathrm{Me}} \mathrm{H}$ was prepared by a literature route. ${ }^{[41]}$ Potassium or lithium salts of the acNac and NacNac ligands were prepared by the general procedure as described previously by our lab. ${ }^{[17]}$ Tetrabutylammonium hexafluorophosphate $\left(\mathrm{TBAPF}_{6}\right)$ was recrystallized from hot ethanol and ferrocene was sublimed before use in electrochemical experiments.

Physical Methods: ${ }^{1} \mathrm{H}$ and ${ }^{13} \mathrm{C}\left\{{ }^{1} \mathrm{H}\right\}$ NMR spectra were recorded at room temperature using a JEOL ECA-400, ECA-500, or ECA-600 NMR spectrometer. UV-vis absorption spectra were recorded in THF solution in screw-capped quartz cuvettes using an Agilent Carey 60 UV-vis spectrophotometer. Luminescence lifetimes were measured with a Horiba DeltaFlex Lifetime System, using $390 \mathrm{~nm}$ pulsed diode excitation. Steadystate emission spectra were recorded using a Horiba FluoroMax-4 spectrofluorometer with appropriate long-pass filters to exclude stray excitation light from detection. In order to exclude air, samples for emission spectra were prepared in a nitrogen-filled glovebox using anhydrous solvents. Samples for room-temperature emission were housed in $1 \mathrm{~cm}$ quartz cuvettes with septum-sealed screw caps, and samples for lowtemperature emission were contained in a custom quartz EPR tube with high-vacuum valve and immersed in liquid nitrogen using a finger dewar. Solution quantum yields were determined relative to a standard of tetraphenylporphyrin in toluene, which has a reported fluorescence quantum yield $\left(\Phi_{\mathrm{PL}}\right)$ of $0.11 .{ }^{[42]}$ Cyclic voltammetry $(\mathrm{CV})$ measurements were performed with a $\mathrm{CH}$ Instruments $602 \mathrm{E}$ potentiostat interfaced with a nitrogen glovebox via wire feedthroughs. Samples were dissolved in acetonitrile with $0.1 \mathrm{M} \mathrm{TBAPF}_{6}$ as a supporting electrolyte. A $3 \mathrm{~mm}$ diameter glassy-carbon working electrode, a platinum wire counter electrode, and a silver wire pseudo-reference electrode were used. Potentials were referenced to an internal standard of ferrocene.

Preparation of (Cy) $\mathrm{acNac}^{\mathrm{Me}} \mathrm{H}$. Acetylacetone $(5.00 \mathrm{~g}, 50 \mathrm{mmol}$, 1.0 equiv) and cyclohexylamine $(4.46 \mathrm{~g}, 45 \mathrm{mmol}, 0.9$ equiv) were dissolved into $20 \mathrm{~mL}$ of DCM and the solution was stirred at roomtemperature for two days. To the opaque, yellow mixture $20 \mathrm{~mL}$ of water were added and the organic layer was separated and dried over $\mathrm{Na}_{2} \mathrm{SO}_{4}$. The solvent was removed under reduced pressure and gave a yellow liquid. Analysis by ${ }^{1} \mathrm{H}$ NMR spectroscopy (Figure S25) indicated sufficient purity for further use. Yield $5.59 \mathrm{~g}(69 \%) .{ }^{1} \mathrm{H}-\mathrm{NMR}\left(400 \mathrm{MHz}, \mathrm{CDCl}_{3}\right) \delta: 10.97$ (bs, $1 \mathrm{H}, \mathrm{NH}), 4.89(\mathrm{~s}, 1 \mathrm{H},(\mathrm{C}=\mathrm{O}) \mathrm{CH}(\mathrm{C}=\mathrm{N})), 3.32-3.37(\mathrm{~m}, 1 \mathrm{H}, \mathrm{CyH}), 1.97$ $\left(\mathrm{s}, 3 \mathrm{H}, \mathrm{CH}_{3}\right), 1.92\left(\mathrm{~s}, 3 \mathrm{H}, \mathrm{CH}_{3}\right), 1.75-1.87(\mathrm{~m}, 4 \mathrm{H}, \mathrm{Cy}), 1.50-1.58(\mathrm{~m}, 1 \mathrm{H}$, Сy), $1.23-1.37$ (m, 5H, Cy).

Preparation of $\operatorname{Ir}(\mathbf{p i q})_{2}\left[(\mathrm{dmp})_{2} \mathrm{NacNac}^{\mathrm{Me}}\right]$ (1a). In the glovebox, $\left[\operatorname{lr}(\mathrm{piq})_{2}(\mu-\mathrm{Cl})\right]_{2}(50 \mathrm{mg}, 0.039 \mathrm{mmol})$ was suspended in $3 \mathrm{~mL} \mathrm{THF}$, and a solution of (dmp) ${ }_{2} \mathrm{NacNac}^{\mathrm{MeK}}$ ( $29 \mathrm{mg}, 0.089 \mathrm{mmol}, 2.3$ equiv) in $5 \mathrm{~mL}$ THF was added to the dimer suspension slowly by pipet. The resulting reddishbrown mixture was stirred overnight at room temperature, during which time the color of the solution changed to dark red. The solvent was removed under reduced pressure, and the resulting residue was extracted with $5 \mathrm{~mL}$ of toluene and filtered through Celite to remove $\mathrm{KCl}$ and other insoluble impurities. The toluene was removed in vacuo, and the residue was washed with $2 \times 3 \mathrm{~mL}$ of room-temperature $\mathrm{Et}_{2} \mathrm{O}$. The final product was obtained by adding pentane to a concentrated DCM solution which was dried under vacuum. Yield: $37 \mathrm{mg}(53 \%) .{ }^{1} \mathrm{H} \mathrm{NMR}\left(600 \mathrm{MHz}, \mathrm{CDCl}_{3}\right)$ ס: 9.23 (d, $J=6.2 \mathrm{~Hz}, 2 \mathrm{H}, \mathrm{ArH}), 8.57(\mathrm{~d}, J=8.9 \mathrm{~Hz}, 2 \mathrm{H}, \mathrm{ArH}), 7.89$ (d, $J=$ $8.2 \mathrm{~Hz}, 2 \mathrm{H}, \mathrm{ArH}), 7.64-7.72(\mathrm{~m}, 4 \mathrm{H}, \mathrm{ArH}), 7.60$ (t, $J=7.6 \mathrm{~Hz}, 2 \mathrm{H}, \mathrm{ArH})$, $7.42(\mathrm{~d}, J=6.2 \mathrm{~Hz}, 2 \mathrm{H}, \mathrm{ArH}), 6.56-6.67(\mathrm{~m}, 6 \mathrm{H}, \mathrm{ArH}), 6.17-6.29(\mathrm{~m}, 4 \mathrm{H}$, ArH $), \quad 5.99(\mathrm{~d}, \quad J=7.6 \quad \mathrm{~Hz}, \quad 2 \mathrm{H}, \quad \operatorname{ArH}), 4.79 \quad(\mathrm{~s}, \quad 1 \mathrm{H}$, $\left.(\mathrm{Me})_{2} \mathrm{PhNC}(\mathrm{Me}) \mathrm{CHC}(\mathrm{Me}) \mathrm{NPh}(\mathrm{Me})_{2}\right), 2.04\left(\mathrm{~s}, 6 \mathrm{H}, \mathrm{CH}_{3}\right), 1.51\left(\mathrm{~s}, 6 \mathrm{H}, \mathrm{CH}_{3}\right)$, $0.875\left(\mathrm{~s}, 6 \mathrm{H}, \mathrm{CH}_{3}\right) \cdot{ }^{13} \mathrm{C}\left\{{ }^{1} \mathrm{H}\right\} \mathrm{NMR}\left(151 \mathrm{MHz}, \mathrm{CDCl}_{3}\right) \delta: 171.3,159.8,155.2$, $149.7,146.5,146.3,136.8,133.0,132.7,131.7,130.5,129.2,128.1,127.8$, $127.5,127.4,127.3,126.5,126.4,125.7,122.7,119.6,117.5,96.74,25.26$, 21.53, 17.02. UV-vis (THF): $\mathrm{N} / \mathrm{nm}\left(\varepsilon / \mathrm{M}^{-1} \mathrm{~cm}^{-1}\right) 302(98000), 343(\mathrm{sh})(50000)$, 390(sh)(20000), 468(21000).

Preparation of $\operatorname{Ir}(\text { piq })_{2}\left(\mathrm{NacNac}^{\mathrm{NMe}}\right)$ (1b). In the glovebox, $\left[\operatorname{Ir}(\mathrm{piq})_{2}(\mu-\mathrm{Cl})\right]_{2}$ ( $60 \mathrm{mg}, 0.047 \mathrm{mmol}$ ) was suspended in $3 \mathrm{~mL}$ of THF, and a solution of $\mathrm{NacNac}{ }^{\mathrm{NM} 2} \mathrm{~K}$ ( $35 \mathrm{mg}, 0.010 \mathrm{mmol}, 2.2$ equiv) in $5 \mathrm{~mL}$ of THF was added to the dimer suspension slowly by pipet. The resulting reddish orange mixture was stirred overnight at room temperature, during which time the color of the solution changed to dark green. The solvent was removed under reduced pressure, and the resulting residue was extracted with 5 $\mathrm{mL}$ of toluene and filtered through Celite to remove $\mathrm{KCl}$ and other insoluble impurities. The toluene was removed in vacuo, and the residue was washed with $2 \times 3 \mathrm{~mL}$ of room-temperature $\mathrm{Et}_{2} \mathrm{O}$. Final product was obtained by adding pentane to a concentrated DCM solution which was dried under vacuum. Yield: $62 \mathrm{mg}(73 \%) .{ }^{1} \mathrm{H}$ NMR $\left(400 \mathrm{MHz}, \mathrm{CDCl}_{3}\right) \delta$ : $8.73(\mathrm{~d}, J=8.9 \mathrm{~Hz}, 2 \mathrm{H}, \mathrm{ArH}), 8.51(\mathrm{~d}, J=6.9 \mathrm{~Hz}, 2 \mathrm{H}, \mathrm{ArH}), 8.03(\mathrm{~d}, J=$ $8.2 \mathrm{~Hz}, 2 \mathrm{H}, \mathrm{ArH}), 7.71$ (d, $J=8.2 \mathrm{~Hz}, 2 \mathrm{H}, \mathrm{ArH}), 7.47-7.58(\mathrm{~m}, 4 \mathrm{H}, \mathrm{ArH})$, $6.96(\mathrm{~d}, J=6.2 \mathrm{~Hz}, 2 \mathrm{H}, \mathrm{ArH}), 6.85(\mathrm{t}, J=7.6 \mathrm{~Hz}, 2 \mathrm{H}, \mathrm{ArH}), 6.47-6.65(\mathrm{~m}$, $8 \mathrm{H}, \mathrm{ArH}), 6.32(\mathrm{t}, J=7.6 \mathrm{~Hz}, 2 \mathrm{H}, \mathrm{ArH}), 6.04(\mathrm{~d}, J=8.2 \mathrm{~Hz}, 2 \mathrm{H}, \mathrm{ArH}), 3.83$ 
(s, 1H, PhNC(NMe $\left.) \mathrm{CHC}\left(\mathrm{NMe}_{2}\right) \mathrm{NPh}\right), 2.29\left(\mathrm{~s}, 12 \mathrm{H}, \mathrm{CH}_{3}\right) .{ }^{13} \mathrm{C}\left\{{ }^{1} \mathrm{H}\right\} \mathrm{NMR}$ $\left(151 \mathrm{MHz}, \mathrm{CDCl}_{3}\right)$ $\delta: 170.1,167.8,162.3,153.8,146.2,144.6,136.5$, 133.2, 130.2, 129.9, 128.2, 127.1, 127.0, 126.5, 126.2, 125.7, 125.6, 119.4 119.3, 117.0, 86.17, 40.99. UV-vis (THF): $\lambda / \mathrm{nm}\left(\varepsilon / \mathrm{M}^{-1} \mathrm{~cm}^{-1}\right) 302(94000)$, 370(sh)(24000), 500(4000).

Preparation of $\operatorname{Ir}(\mathbf{p i q})_{2}$ (dipba $\left.^{\text {mes }}\right)$ (1c). In the glovebox, 2bromomesitylene ( $36 \mathrm{mg}, 0.18 \mathrm{mmol}$ ) was dissolved in $5 \mathrm{~mL} \mathrm{THF}$ and the solution was kept at $-35^{\circ} \mathrm{C}$ for $1 \mathrm{~h}$. After that a hexane solution of $n$-BuLi $(\sim 0.11 \mathrm{~mL}, 1.6 \mathrm{M})$ was added, and the reaction mixture was stirred at $-35^{\circ} \mathrm{C}$ for $10 \mathrm{~min}$. Then $\mathrm{N}, \mathrm{N}^{\prime}$-diisopropylcarbodiimide ( $\left.23 \mathrm{mg}, 0.18 \mathrm{mmol}\right)$ was added to the solution and the reaction mixture was stirred at room temperature for another $10 \mathrm{~min}$. The colorless solution was then added dropwise to a Teflon-capped glass tube containing $\left[\operatorname{Ir}(p i q){ }_{2}(\mu-\mathrm{Cl})\right]_{2}(100 \mathrm{mg}$ $0.0786 \mathrm{mmol}$ ) in $5 \mathrm{~mL}$ THF. The resulting reddish orange mixture was stirred overnight outside of glovebox at $80-85^{\circ} \mathrm{C}$, during which time the color of the solution changed to dark brown. The mixture was cooled to room temperature and the sealed tube was taken inside the glovebox for further workup procedure. The solvent was removed under reduced pressure and the residue was extracted in $2 \mathrm{~mL}$ toluene and evaporated under reduced pressure to remove THF completely. The product was redissolved in $10 \mathrm{~mL}$ toluene and filtered through Celite to remove $\mathrm{LiCl}$ and other insoluble impurities. The crude product was washed with $3 \times 3 \mathrm{~mL}$ of $\mathrm{Et}_{2} \mathrm{O}$ and $2 \times 3$ of $\mathrm{mL}$ hexane. The solid was redissolved in minimum amount of DCM and pentane was added to slowly induce precipitation and the resulted reddish-brown solid was concentrated to dryness. Yield: 55 $\mathrm{mg}(48 \%) .{ }^{1} \mathrm{H}$ NMR $\left(600 \mathrm{MHz}, \mathrm{CDCl}_{3}\right) \delta: 9.55(\mathrm{~d}, J=6.4 \mathrm{~Hz}, 2 \mathrm{H}, \mathrm{ArH})$, $8.96(\mathrm{~d}, J=8.2 \mathrm{~Hz}, 2 \mathrm{H}, \mathrm{ArH}), 8.17(\mathrm{~d}, J=7.8 \mathrm{~Hz}, 2 \mathrm{H}, \mathrm{ArH}), 7.96(\mathrm{~d}, J=$ $7.3 \mathrm{~Hz}, 2 \mathrm{H}, \mathrm{ArH}), 7.63-7.75(\mathrm{~m}, 4 \mathrm{H}, \mathrm{ArH}), 7.53(\mathrm{~d}, J=6.4 \mathrm{~Hz}, 2 \mathrm{H}, \mathrm{ArH})$, 6.77-6.93 (m, 4H, ArH), 6.61-6.67 (m, 2H, ArH), $6.36(\mathrm{~d}, J=7.8 \mathrm{~Hz}, 2 \mathrm{H}$, ArH), 3.04 (sept, $J=6.2 \mathrm{~Hz}, 2 \mathrm{H},\left(\mathrm{CH}_{3}\right)_{2} \mathrm{CHN}$ ), $2.43\left(\mathrm{~s}, 6 \mathrm{H}, \mathrm{CH}_{3}\right), 2.25$ (s, $\left.6 \mathrm{H}, \mathrm{CH}_{3}\right), 0.72\left(\mathrm{~d}, J=5.6 \mathrm{~Hz}, 6 \mathrm{H}, \mathrm{CH}_{3}\right),-0.06\left(\mathrm{~d}, J=6.4 \mathrm{~Hz}, 6 \mathrm{H}, \mathrm{CH}_{3}\right)$. ${ }^{13} \mathrm{C}\left\{{ }^{1} \mathrm{H}\right\} \mathrm{NMR}\left(151 \mathrm{MHz}, \mathrm{CDCl}_{3}\right) \delta: 173.0,170.1,159.5,146.3,145.8,137.2$, $136.5,136.2,133.7,132.6,130.2,129.7,128.8,128.3,127.3,127.2,127.1$ 126.2, 119.2, 119.0, 48.73, 25.17, 24.88, 21.33, 21.14. UV-vis (THF): $\mathrm{N} / \mathrm{nm}$ $\left(\varepsilon / \mathrm{M}^{-1} \mathrm{~cm}^{-1}\right)$ 302(87000), 337(44000), 393(sh)(16000), 476(19000), $582(\mathrm{sh})(4000)$.

Preparation of $\operatorname{Ir}(\mathbf{p i q})_{2}\left(\mathbf{d i p g}^{\mathrm{NMe}}\right)$ (1d). In the glovebox, lithium dimethylamide $(\sim 4 \mathrm{mg}, 0.08 \mathrm{mmol})$ was dissolved in $5 \mathrm{~mL}$ THF and the solution was kept at $-35^{\circ} \mathrm{C}$ for $1 \mathrm{~h}$. After that $\mathrm{N}, \mathrm{N}^{\prime}$-diisopropylcarbodiimide (11 $\mathrm{mg}, 0.083 \mathrm{mmol}$ ) was added to the solution and the mixture was stirred at room temp for $30 \mathrm{~min}$. The colorless guanidinate solution was then added dropwise to the Teflon-capped glass tube containing $\left[\operatorname{lr}(\mathrm{piq})_{2}(\mu-\mathrm{Cl})\right]_{2}$ (50 mg, $0.039 \mathrm{mmol}$ ) in $5 \mathrm{~mL}$ THF. The resulting red mixture was stirred overnight outside of the glovebox at $80-85^{\circ} \mathrm{C}$, during which time the color of the solution changed to light brown. The mixture was cooled to room temperature and the sealed tube was taken inside the glovebox for further workup procedure. The solvent was removed under reduced pressure and the residue was extracted in $3 \mathrm{~mL}$ of toluene and evaporated under reduced pressure to remove THF completely. The product was redissolved in $5 \mathrm{~mL}$ of toluene and filtered through Celite to remove $\mathrm{LiCl}$ and other insoluble impurities. The crude product was washed with $3 \times 3 \mathrm{~mL}$ of $\mathrm{Et}_{2} \mathrm{O}$ and $2 \times 3 \mathrm{~mL}$ of pentane. The crude product was redissolved in minimum amount of THF and pentane was added to the solution to slowly induced precipitation. The light brown solid was washed again with $2 \times 2 \mathrm{~mL}$ of $\mathrm{Et}_{2} \mathrm{O}$ and the resulting solution was concentrated to dryness. Yield: $33 \mathrm{mg}$ (54\%). ${ }^{1} \mathrm{H} \mathrm{NMR}\left(600 \mathrm{MHz}, \mathrm{CDCl}_{3}\right)$ ס: $9.32(\mathrm{~d}, J=6.3 \mathrm{~Hz}, 2 \mathrm{H}, \mathrm{ArH}), 8.92$ (d, $J=8.0 \mathrm{~Hz}, 2 \mathrm{H}, \mathrm{ArH}), 8.13(\mathrm{~d}, J=8.0 \mathrm{~Hz}, 2 \mathrm{H}, \mathrm{ArH}), 7.93(\mathrm{~d}, J=7.4 \mathrm{~Hz}, 2 \mathrm{H}$, ArH), 7.59-7.76 (m, 4H, ArH), $7.48(\mathrm{~d}, J=6.3 \mathrm{~Hz}, 2 \mathrm{H}, \mathrm{ArH}), 6.80(\mathrm{t}, J=$ $7.4 \mathrm{~Hz}, 2 \mathrm{H}, \mathrm{ArH}), 6.56(\mathrm{~d}, J=6.9 \mathrm{~Hz}, 2 \mathrm{H}, \mathrm{ArH}), 6.22(\mathrm{~d}, J=7.4 \mathrm{~Hz}, 2 \mathrm{H}$, ArH), 3.71 (sept, $\left.J=6.3 \mathrm{~Hz}, 2 \mathrm{H},\left(\mathrm{CH}_{3}\right)_{2} \mathrm{CHN}\right), 2.86\left(\mathrm{~s}, 6 \mathrm{H}, \mathrm{CH}_{3}\right), 0.57$ (d, $J$ $\left.=6.3 \mathrm{~Hz}, 6 \mathrm{H}, \mathrm{CH}_{3}\right),-0.05\left(\mathrm{~d}, J=6.3 \mathrm{~Hz}, 6 \mathrm{H}, \mathrm{CH}_{3}\right) \cdot{ }^{13} \mathrm{C}\left\{{ }^{1} \mathrm{H}\right\} \mathrm{NMR}(151 \mathrm{MHz}$, $\left.\mathrm{CDCl}_{3}\right)$ ठ: 170.2, 169.9, 161.2, 146.2, 143.3, 136.2, 132.6, 130.0, 129.8,
128.7, 127.2, 127.1, 126.4, 119.1, 118.9, 47.66, 40.77, 24.79, 24.33. UVvis (THF): $\lambda / \mathrm{nm}\left(\varepsilon / \mathrm{M}^{-1} \mathrm{~cm}^{-1}\right) 305(57000), 341(\mathrm{sh})(31000), 464(16000)$, 583(sh)(4000).

Preparation of $\operatorname{Ir}(\text { piq })_{2}\left[(\mathrm{Cy})_{2} \mathrm{NacNac}^{\mathrm{Me}}\right]$ (1e). In the glovebox, $\left[\operatorname{Ir}(\mathrm{piq})_{2}(\mu-\right.$ $\mathrm{Cl})]_{2}(100 \mathrm{mg}, 0.079 \mathrm{mmol}$ ) was suspended in $5 \mathrm{~mL}$ of toluene in a Tefloncapped glass tube. A suspension of $\left[(\mathrm{Cy})_{2} \mathrm{NacNac}\right] \mathrm{K}(45 \mathrm{mg}, 0.15 \mathrm{mmol})$ in $5 \mathrm{~mL}$ of toluene was added into the tube slowly via pipette. The reaction mixture was heated outside of glovebox at $130{ }^{\circ} \mathrm{C}$ for five days. The mixture was cooled to room temperature and the sealed tube was taken inside the glovebox for further workup procedure. The resulting dark mixture was filtered through Celite and concentrated in vacuo. The residue was crystallized using $2 \mathrm{~mL}$ of $\mathrm{Et}_{2} \mathrm{O}$ at $-30^{\circ} \mathrm{C}$. The supernatant liquid was removed via pipette and the solid residue was washed again with $2 \times 3 \mathrm{~mL}$ of $\mathrm{Et}_{2} \mathrm{O}$ at $-30^{\circ} \mathrm{C}$ and $3 \times 3 \mathrm{~mL}$ of pentane. The resulting solid was dried in vacuo and obtained as dark brown solid. Yield: $47 \mathrm{mg}(37 \%) .{ }^{1} \mathrm{H}-\mathrm{NMR}$ $\left(500 \mathrm{MHz}, \mathrm{CD}_{2} \mathrm{Cl}_{2}\right) \delta: 9.07(\mathrm{~d}, J=6.3 \mathrm{~Hz}, 2 \mathrm{H}, \mathrm{Ar} H), 8.91(\mathrm{~d}, J=8.0 \mathrm{~Hz}$, $2 \mathrm{H}, \operatorname{ArH}), 8.14(\mathrm{~d}, J=8.0 \mathrm{~Hz}, 2 \mathrm{H}, \operatorname{ArH}), 7.93(\mathrm{~d}, J=7.4 \mathrm{~Hz}, 2 \mathrm{H}, \operatorname{ArH})$, 7.65-7.71 (m, 4H, ArH), $7.42(\mathrm{~d}, J=6.3 \mathrm{~Hz}, 2 \mathrm{H}, \operatorname{ArH}), 6.85(\mathrm{t}, J=7.4 \mathrm{~Hz}$, $2 \mathrm{H}, \quad \operatorname{ArH}), \quad 6.56(\mathrm{t}, \quad J=7.2 \mathrm{~Hz}, 2 \mathrm{H}, \quad \operatorname{ArH}), 4.00(\mathrm{~s}, \quad 1 \mathrm{H}$, CyNC(Me)CHC(Me)NCy ), 2.97 (t, $J=11.5 \mathrm{~Hz}, 2 \mathrm{H}, \mathrm{CyH}), 1.89(\mathrm{~s}, 6 \mathrm{H}$, $\left.\mathrm{CH}_{3}\right), 1.59-1.63(\mathrm{~m}, 4 \mathrm{H}, \mathrm{Cy}), 1.12-1.32(\mathrm{~m}, 6 \mathrm{H}, \mathrm{Cy}), 0.90-0.99(\mathrm{~m}, 2 \mathrm{H}$, Cy), 0.63-0.71 (m, 2H, Cy), 0.50-0.54 (m, 2H, Cy), 0.30-0.40 (m, 2H, Cy), $0.01-0.07$ (m, 2H, Cy). ${ }^{13} \mathrm{C}\left\{{ }^{1} \mathrm{H}\right\} \mathrm{NMR}\left(126 \mathrm{MHz}, \mathrm{CD}_{2} \mathrm{Cl}_{2}\right) \delta: 169.67,162.76$, $158.34,146.51,144.38,136.82,132.25,130.37,129.74,128.65,127.22$, 126.99, 126.91, 126.35, 119.38, 118.51, 99.84, 66.35, 34.41, 33.75, 26.94, 26.30, 26.09, 24.88. UV-vis (THF): $\lambda / \mathrm{nm}\left(\varepsilon / \mathrm{M}^{-1} \mathrm{~cm}^{-1}\right) 299$ (38000), 405(17000), 533(sh)(12000).

Preparation of $\operatorname{Ir}(\mathbf{p i q})_{2}\left[(\mathrm{Cy}) \mathrm{acNac}^{\mathrm{Me}}\right]$ (1f). In the glovebox, $\left[\mathrm{Ir}(\mathrm{piq})_{2}(\mu-\mathrm{Cl})\right]_{2}$ $(100 \mathrm{mg}, 0.079 \mathrm{mmol})$ was suspended in $5 \mathrm{~mL}$ of toluene in a Tefloncapped glass tube. A suspension of (Cy)acNac ${ }^{\mathrm{Me}} \mathrm{K}(33 \mathrm{mg}, 0.15 \mathrm{mmol})$ in $5 \mathrm{~mL}$ of toluene was added into the tube slowly via pipette. The reaction mixture was heated outside of glovebox at $130{ }^{\circ} \mathrm{C}$ for five days. The mixture was cooled to room temperature and the sealed tube was taken inside the glovebox for further workup procedure. The resulting dark red mixture was filtered through Celite and concentrated in vacuo. The residue was crystallized using $2 \mathrm{~mL}$ of $\mathrm{Et}_{2} \mathrm{O}$ at $-35^{\circ} \mathrm{C}$. The supernatant liquid was removed via pipette and the solid residue was washed again with $2 \times 3 \mathrm{~mL}$ of cold $\mathrm{Et}_{2} \mathrm{O}$ and $3 \times 3 \mathrm{~mL}$ of pentane. The resulting solid was dried in vacuo and obtained as dark red solid. Yield: $41 \mathrm{mg}(35 \%)$. ${ }^{1} \mathrm{H}-\mathrm{NMR}(400$ $\left.\mathrm{MHz}, \mathrm{CD}_{2} \mathrm{Cl}_{2}\right) \delta$ : 8.98-9.04 (m, $\left.1 \mathrm{H}, \mathrm{ArH}\right), 8.92(\mathrm{~d}, J=7.8 \mathrm{~Hz}, 1 \mathrm{H}, \mathrm{ArH})$, $8.75(\mathrm{q}, J=6.6 \mathrm{~Hz}, 2 \mathrm{H}, \mathrm{ArH}), 8.30(\mathrm{~d}, J=8.2 \mathrm{~Hz}, 1 \mathrm{H}, \operatorname{ArH}), 8.15(\mathrm{~d}, J=$ $7.8 \mathrm{~Hz}, 1 \mathrm{H}, \mathrm{ArH}), 7.92-7.99(\mathrm{~m}, 2 \mathrm{H}, \mathrm{ArH}), 7.66-7.75(\mathrm{~m}, 4 \mathrm{H}, \mathrm{ArH}), 7.48$ (dd, $J=6.4,29 \mathrm{~Hz}, 2 \mathrm{H}, \mathrm{ArH}), 6.91(\mathrm{q}, J=7.2 \mathrm{~Hz}, 2 \mathrm{H}, \mathrm{ArH}), 6.58-6.70(\mathrm{~m}$, $2 \mathrm{H}, \operatorname{ArH}), 6.45(\mathrm{~d}, J=7.8 \mathrm{~Hz}, 1 \mathrm{H}, \operatorname{ArH}), 6.19(\mathrm{~d}, J=6.9 \mathrm{~Hz}, 1 \mathrm{H}, \operatorname{ArH}), 4.56$ (s, $1 \mathrm{H}, \mathrm{CyNC}(\mathrm{Me}) \mathrm{CHC}(\mathrm{O}) \mathrm{Me}$ ), $3.06(\mathrm{~s}, 1 \mathrm{H}, \mathrm{CyH}), 1.99\left(\mathrm{~s}, 3 \mathrm{H}, \mathrm{CH}_{3}\right), 1.59$ (s, 3H, CH $\mathrm{CH}_{3}, 0.96-1.43(\mathrm{~m}, 5 \mathrm{H}, \mathrm{Cy}), 0.60-0.92(\mathrm{~m}, 1 \mathrm{H}, \mathrm{Cy}), 0.01-0.48(\mathrm{~m}$, $3 \mathrm{H}, \mathrm{Cy}) .{ }^{13} \mathrm{C}\left\{{ }^{1} \mathrm{H}\right\}$ NMR $\left(126 \mathrm{MHz}, \mathrm{CD}_{2} \mathrm{Cl}_{2}\right) \delta: 173.73,169.38,168.70$, $163.12,158.47,157.57,147.01,146.22,142.97,141.42,137.03,136.89$, $133.16,132.33,130.59,130.56,130.34,129.63,129.07,128.30,127.75$, $127.52,127.04,126.94,126.46,126.41,126.32,120.55,119.83,119.37$, $99.77,66.07,32.40,31.97,26.51,26.21,25.73$. UV-vis (THF): $\lambda / \mathrm{nm}^{\left(\varepsilon / \mathrm{M}^{-}\right.}$ ${ }^{1} \mathrm{~cm}^{-1}$ ) 298(36000), 322(sh)(23000), 384(sh)(11000), 486(5300).

Preparation of $\operatorname{Ir}(\mathrm{btp})_{2}\left[(\mathrm{dmp})_{2} \mathrm{NacNac}^{\mathrm{Me}}\right]$ (2a). Prepared by the method described above for complex 1a, using $\left[\operatorname{lr}(\mathrm{btp})_{2}(\mu-\mathrm{Cl})_{2}\right](50 \mathrm{mg}, 0.038$ $\mathrm{mmol}$ ) and $(\mathrm{dmp})_{2} \mathrm{NacNac}^{\mathrm{Me} K}(30 \mathrm{mg}, 0.089 \mathrm{mmol})$. The purified product was a dark orange colored solid. Yield: $43 \mathrm{mg}(63 \%) .{ }^{1} \mathrm{H}$ NMR $(600 \mathrm{MHz}$, $\left.\mathrm{CDCl}_{3}\right) \delta: 9.24(\mathrm{~d}, J=6.2 \mathrm{~Hz}, 2 \mathrm{H}, \mathrm{ArH}), 7.70(\mathrm{t}, J=7.6 \mathrm{~Hz}, 2 \mathrm{H}, \mathrm{ArH}), 7.33$ (d, $J=7.6 \mathrm{~Hz}, 2 \mathrm{H}, \operatorname{ArH}), 7.27(\mathrm{~d}, J=7.6 \mathrm{~Hz}, 2 \mathrm{H}, \operatorname{ArH}), 7.03(\mathrm{t}, J=6.2 \mathrm{~Hz}$, $2 \mathrm{H}, \mathrm{ArH}), 6.86(\mathrm{t}, J=6.9 \mathrm{~Hz}, 2 \mathrm{H}, \mathrm{ArH}), 6.57(\mathrm{t}, J=7.6 \mathrm{~Hz}, 2 \mathrm{H}, \mathrm{ArH}), 6.38$ $6.47(\mathrm{~m}, 4 \mathrm{H}, \mathrm{ArH}), 5.95(\mathrm{~d}, J=6.9 \mathrm{~Hz}, 2 \mathrm{H}, \mathrm{ArH}), 5.90(\mathrm{~d}, J=8.3 \mathrm{~Hz}, 2 \mathrm{H}$, $\mathrm{ArH}), 4.79\left(\mathrm{~s}, 1 \mathrm{H},(\mathrm{Me})_{2} \mathrm{PhNC}(\mathrm{Me}) \mathrm{CHC}(\mathrm{Me}) \mathrm{NPh}(\mathrm{Me})_{2}\right), 1.82\left(\mathrm{~s}, 6 \mathrm{H}, \mathrm{CH}_{3}\right)$, 
$1.68\left(\mathrm{~s}, 6 \mathrm{H}, \mathrm{CH}_{3}\right), 1.32\left(\mathrm{~s}, 6 \mathrm{H}, \mathrm{CH}_{3}\right) .{ }^{13} \mathrm{C}\left\{{ }^{1} \mathrm{H}\right\} \mathrm{NMR}\left(151 \mathrm{MHz}, \mathrm{CDCl}_{3}\right): 167.5$ 159.2, 155.0, 152.5, 148.5, 146.1, 142.4, 137.6, 136.0, 133.0, 132.6, 127.4 $126.9,126.0,124.0,123.4,122.2,122.0,117.5,117.4,98.08,25.61,23.88$ 17.53. UV-vis (THF): $\quad \lambda / \mathrm{nm}\left(\varepsilon / \mathrm{M}^{-1} \mathrm{~cm}^{-1}\right) \quad 297(51000), \quad 332(36000)$, 359(33000), 383(sh)(32000), 498(sh)(5000).

Preparation of $\operatorname{Ir}(\mathbf{b t p})_{2}\left(\mathrm{NacNac}^{\mathrm{NMe} 2}\right)$ (2b). Prepared by the method described above for complex 1b, using $\left[\operatorname{lr}(\mathrm{btp})_{2}(\mu-\mathrm{Cl})_{2}\right](50 \mathrm{mg}, 0.038$ $\mathrm{mmol}$ ) and (dmp) ${ }_{2} \mathrm{NacNac}^{\mathrm{MeK}}(27 \mathrm{mg}, 0.078 \mathrm{mmol}, 2.1$ equiv). The purified product was a light orange colored solid. Yield: $35 \mathrm{mg}(50 \%)$. ${ }^{1} \mathrm{H}$ NMR $(400$ $\left.\mathrm{MHz}, \mathrm{CDCl}_{3}\right) \delta: 8.75(\mathrm{~d}, J=5.5 \mathrm{~Hz}, 2 \mathrm{H}, \mathrm{ArH}), 7.60(\mathrm{~d}, J=8.2 \mathrm{~Hz}, 2 \mathrm{H}, \mathrm{ArH})$, $7.43(\mathrm{t}, J=6.9 \mathrm{~Hz}, 2 \mathrm{H}, \mathrm{ArH}), 7.13-7.17(\mathrm{~m}, 2 \mathrm{H}, \mathrm{ArH}), 6.99(\mathrm{t}, J=8.2 \mathrm{~Hz}$, $2 \mathrm{H}, \mathrm{ArH}), 6.66-6.76(\mathrm{~m}, 4 \mathrm{H}, \mathrm{ArH}), 6.44-6.58(\mathrm{~m}, 6 \mathrm{H}, \mathrm{ArH}), 6.09(\mathrm{~d}, J=8.2$ $\mathrm{Hz}, 2 \mathrm{H}, \quad \operatorname{ArH}), 5.96(\mathrm{~d}, J=7.6 \mathrm{~Hz}, 4 \mathrm{H}, \quad A r H), 4.06(\mathrm{~s}, 1 \mathrm{H}$, $\left.\mathrm{PhNC}\left(\mathrm{NMe}_{2}\right) \mathrm{CHC}\left(\mathrm{NMe}_{2}\right) \mathrm{NPh}\right), 2.38\left(\mathrm{~s}, 12 \mathrm{H}, \mathrm{CH}_{3}\right) .{ }^{13} \mathrm{C}\left\{{ }^{1} \mathrm{H}\right\} \mathrm{NMR}(151$ $\left.\mathrm{MHz}, \mathrm{CDCl}_{3}\right)$ ס: $167.1,166.7,155.4,152.4,151.1,147.4,142.5,136.7$, 135.0, 129.1, 128.3, 127.1, 126.3, 126.1, 124.4, 123.2, 122.5, 119.6, 117.2 116.9, 84.61, 41.21. UV-vis (THF): $\lambda / \mathrm{nm}\left(\varepsilon / \mathrm{M}^{-1} \mathrm{~cm}^{-1}\right)$ 296(58000), 370 (sh)(24000), 500(4000).

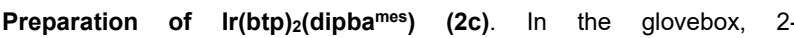
bromomesitylene ( $\sim 33 \mathrm{mg}, 0.17 \mathrm{mmol})$ was dissolved in $5 \mathrm{~mL} \mathrm{THF}$ and the solution was kept at $-35^{\circ} \mathrm{C}$ for $1 \mathrm{~h}$. After that a hexane solution of $n$-BuLi $(\sim 0.11 \mathrm{~mL}, 1.6 \mathrm{M})$ was added, and the reaction mixture was stirred at $-35^{\circ}$ $\mathrm{C}$ for $10 \mathrm{~min}$. Then $\mathrm{N}, \mathrm{N}^{\prime}$-diisopropylcarbodiimide $(\sim 21 \mathrm{mg}, 0.17 \mathrm{mmol})$ was added to the solution and the reaction mixture was stirred at room temp for $10 \mathrm{~min}$. The colorless solution was then added dropwise to the Tefloncapped glass tube containing $\left[\operatorname{Ir}(\mathrm{btp})_{2}(\mu-\mathrm{Cl})\right]_{2}(100 \mathrm{mg}, 0.0769 \mathrm{mmol})$ in 5 $\mathrm{mL}$ of THF. The resulting yellow mixture was stirred overnight outside of glovebox at $80-85^{\circ} \mathrm{C}$, during which time the color of the solution changed to light orange. The mixture was cooled to room temperature and the sealed tube was taken inside the glovebox for further workup procedure. The solvent was removed under reduced pressure and the residue was extracted into $3 \mathrm{~mL}$ of toluene and evaporated under reduced pressure to remove THF completely. The product was redissolved in $15 \mathrm{~mL}$ of toluene and filtered through Celite to remove $\mathrm{LiCl}$ and other insoluble impurities. The crude product was washed with $3 \times 3 \mathrm{~mL}$ of $\mathrm{Et}_{2} \mathrm{O}$ and $2 \times 3$ of $\mathrm{mL}$ hexane. The solid was redissolved in minimum amount of DCM and pentane was added to slowly induce precipitation and the resulted orange solid was concentrated to dryness. Yield: $42 \mathrm{mg}(32 \%) .{ }^{1} \mathrm{H} \mathrm{NMR}(600 \mathrm{MHz}$, $\mathrm{CDCl}_{3}$ ) $\delta: 9.52$ (d, $\left.J=5.5 \mathrm{~Hz}, 2 \mathrm{H}, \mathrm{ArH}\right), 7.77(\mathrm{t}, J=7.9 \mathrm{~Hz}, 2 \mathrm{H}, \mathrm{ArH}), 7.63$ (dd, $J=7.6,35 \mathrm{~Hz}, 4 \mathrm{H}, \mathrm{ArH}), 7.01-7.11(\mathrm{~m}, 4 \mathrm{H}, \mathrm{ArH}), 6.76-6.88(\mathrm{~m}, 4 \mathrm{H}$, ArH), $6.21(\mathrm{~d}, J=8.2 \mathrm{~Hz}, 2 \mathrm{H}, \mathrm{ArH}), 2.96$ (sept, $J=6.2 \mathrm{~Hz}, 2 \mathrm{H},\left(\mathrm{CH}_{3}\right)_{2} \mathrm{CHN}$ ), $2.37\left(\mathrm{~s}, 6 \mathrm{H}, \mathrm{CH}_{3}\right), 2.25\left(\mathrm{~s}, 6 \mathrm{H}, \mathrm{CH}_{3}\right), 0.59\left(\mathrm{~d}, J=6.2 \mathrm{~Hz}, 6 \mathrm{H}, \mathrm{CH}_{3}\right), 0.07$ (d, $\left.J=6.2 \mathrm{~Hz}, 6 \mathrm{H}, \mathrm{CH}_{3}\right) \cdot{ }^{13} \mathrm{C}\left\{{ }^{1} \mathrm{H}\right\} \mathrm{NMR}\left(151 \mathrm{MHz}, \mathrm{CDCl}_{3}\right) \delta: 174.3,167.1$, $154.4,153.5,147.6,142.7,137.7,136.9,136.0,134.5,132.7,128.6,126.0$, $124.7,123.4,122.7,117.4,117.6,48.08,24.75,24.55,21.54,21.15$. UVvis (THF): $N / \mathrm{nm}\left(\varepsilon / \mathrm{M}^{-1} \mathrm{~cm}^{-1}\right)$ 288(64000), 331(40000), 432(13000), 486(sh)(8000), 583(sh)(1000)

Preparation of $\operatorname{Ir}\left(\mathbf{b t p}_{\mathbf{2}} \mathbf{( d i p g}^{\mathrm{NMe}}\right)$ (2d). Prepared by the method described above for complex 1d, using $\left[\operatorname{Ir}(\operatorname{btp})_{2}(\mu-\mathrm{Cl})_{2}\right](100 \mathrm{mg}, 0.0768 \mathrm{mmol})$, lithium dimethylamide $(\sim 8 \mathrm{mg}, 0.16 \mathrm{mmol}, 2.1$ equiv), and $\mathrm{N}, \mathrm{N}$ 'diisopropylcarbodiimide $(\sim 20 \mathrm{mg}, 0.16 \mathrm{mmol})$. The purified product was a light orange colored solid. Yield: $61 \mathrm{mg}(51 \%) .{ }^{1} \mathrm{H} \mathrm{NMR}\left(600 \mathrm{MHz}, \mathrm{CDCl}_{3}\right)$ $\delta: 9.26$ (d, $J=5.5 \mathrm{~Hz}, 2 \mathrm{H}, \mathrm{ArH}$ ), 7.58 (dd, $J=8.3,33 \mathrm{~Hz}, 4 \mathrm{H}, \mathrm{ArH}$ ), $6.97-$ $7.07(\mathrm{~m}, 4 \mathrm{H}, \mathrm{ArH}), 6.76(\mathrm{t}, J=7.6 \mathrm{~Hz}, 2 \mathrm{H}, \mathrm{ArH}), 6.16(\mathrm{~d}, J=7.6 \mathrm{~Hz}, 2 \mathrm{H}$, ArH), 3.60 (septa, $J=6.2 \mathrm{~Hz}, 2 \mathrm{H},\left(\mathrm{CH}_{3}\right)_{2} \mathrm{CHN}$ ), $2.80\left(\mathrm{~s}, 6 \mathrm{H}, \mathrm{CH}_{3}\right), 0.47$ (d, $\left.J=6.2 \mathrm{~Hz}, 6 \mathrm{H}, \mathrm{CH}_{3}\right), 0.01\left(\mathrm{~d}, J=6.2 \mathrm{~Hz}, 6 \mathrm{H}, \mathrm{CH}_{3}\right) \cdot{ }^{13} \mathrm{C}\left\{{ }^{1} \mathrm{H}\right\} \mathrm{NMR}(151 \mathrm{MHz}$, $\left.\mathrm{CDCl}_{3}\right)$ ס: 170.6, 167.2, 151.6, 147.6, 145.5, 142.7, 136.2, 133.6, 125.9, 124.6, 123.2, 122.5, 118.0, 117.7, 47.0, 40.6, 24.2, 24.0. UV-vis (THF): $\mathrm{N} / \mathrm{nm}\left(\varepsilon / \mathrm{M}^{-1} \mathrm{~cm}^{-1}\right)$ 334(48000), 427(19000), 517(10000), 595(sh)(2000).
X-ray Crystallography Details: Single crystals were grown by vapor diffusion of pentane vapor into concentrated THF or dichloromethane solutions. Crystals were mounted on a Bruker Apex II three-circle diffractometer using MoKa radiation $(\lambda=0.71073 \AA)$. The data was collected at 123(2) K and was processed and refined within the APEXII software. Structures were solved by direct methods in SHELXS and refined by standard difference Fourier techniques in the program SHELXL ${ }^{[43]}$ Hydrogen atoms were placed in calculated positions using the standard riding model and refined isotropically; all non-hydrogen atoms were refined anisotropically.

\section{Acknowledgements}

The authors acknowledge the National Science Foundation (CHE-1846831) and the Welch Foundation (grant no. E-1887) for funding this research. B.-L. N. acknowledges the University of Houston for an undergraduate research fellowship through the SURF program.

\section{Conflicts of interest}

The authors declare no conflict of interest.

Keywords: red-emitting $\bullet$ cyclometalated iridium $\bullet$ cyclic voltammetry $\bullet$ ligand modification $\bullet$ luminescence

[1] C. K. Prier, D. A. Rankic, D. W. C. MacMillan, Chem. Rev. 2013, 113, 5322-5363.

[2] Z. Zuo, D. T. Ahneman, L. Chu, J. A. Terrett, A. G. Doyle, D. W. C. MacMillan, Science 2014, 345, 437-440.

[3] T. P. Yoon, M. A. Ischay, J. Du, Nat. Chem. Lond. 2010, 2, 527-32

[4] Q. Zhao, F. Li, S. Liu, M. Yu, Z. Liu, T. Yi, C. Huang, Inorg. Chem. 2008, 47, 9256-9264.

[5] Q. Zhao, F. Li, C. Huang, Chem. Soc. Rev. 2010, 39, 3007-3030.

[6] H. (Hartmut) Yersin, Highly Efficient OLEDs with Phosphorescent Materials, Weinheim : Wiley-VCH, 2008.

[7] S. Lamansky, P. Djurovich, D. Murphy, F. Abdel-Razzaq, H.-E. Lee, C. Adachi, P. E. Burrows, S. R. Forrest, M. E. Thompson, J. Am. Chem. Soc. 2001, 123, 4304-4312.

[8] M. S. Lowry, S. Bernhard, Chem. - Eur. J. 2006, 12, 7970-7977.

[9] M. Sarma, W.-L. Tsai, W.-K. Lee, Y. Chi, C.-C. Wu, S.-H. Liu, P.-T. Chou, K.-T. Wong, Chem 2017, 3, 461-476.

[10] R. D. Costa, E. Orti, H. J. Bolink, F. Monti, G. Accorsi, N. Armaroli, Angew. Chem. Int. Ed. 2012, 51, 8178-8211.

[11] T.-B. Gao, J.-J. Zhang, R.-Q. Yan, D.-K. Cao, D. Jiang, D. Ye, Inorg. Chem. 2018, 57, 4310-4316.

[12] K. Dedeian, P. I. Djurovich, F. O. Garces, G. Carlson, R. J. Watts, Inorg. Chem. 1991, 30, 1685-1687.

[13] A. B. Tamayo, B. D. Alleyne, P. I. Djurovich, S. Lamansky, I. Tsyba, N. N. Ho, R. Bau, M. E. Thompson, J. Am. Chem. Soc. 2003, 125, 73777387 .

[14] Y. You, S. Y. Park, J. Am. Chem. Soc. 2005, 127, 12438-12439.

[15] C.-J. Chang, C.-H. Yang, K. Chen, Y. Chi, C.-F. Shu, M.-L. Ho, Y.-S. Yeh, P.-T. Chou, Dalton Trans. 2007, 1881-1890.

[16] J. Li, P. I. Djurovich, B. D. Alleyne, M. Yousufuddin, N. N. Ho, J. C. Thomas, J. C. Peters, R. Bau, M. E. Thompson, Inorg. Chem. 2005, 44, 1713-1727.

[17] Y. K. Radwan, A. Maity, T. S. Teets, Inorg. Chem. 2015, 54, 71227131.

[18] Md. K. Nazeeruddin, R. Humphry-Baker, D. Berner, S. Rivier, L. Zuppiroli, M. Graetzel, J. Am. Chem. Soc. 2003, 125, 8790-8797.

[19] T. Sajoto, P. I. Djurovich, A. B. Tamayo, J. Oxgaard, W. A. Goddard, M. E. Thompson, J. Am. Chem. Soc. 2009, 131, 9813-9822.

[20] C.-H. Yang, M. Mauro, F. Polo, S. Watanabe, I. Muenster, R. Fröhlich, L. De Cola, Chem. Mater. 2012, 24, 3684-3695. 
[21] N. M. Shavaleev, F. Monti, R. D. Costa, R. Scopelliti, H. J. Bolink, E. Ortí, G. Accorsi, N. Armaroli, E. Baranoff, M. Grätzel, M. K.

Nazeeruddin, Inorg. Chem. 2012, 51, 2263-2271.

[22] S. Haneder, E. D. Como, J. Feldmann, J. M. Lupton, C. Lennartz, P. Erk, E. Fuchs, O. Molt, I. Münster, C. Schildknecht, G. Wagenblast, Adv. Mater. 2008, 20, 3325-3330.

[23] M. Bixon, J. Jortner, J. Chem. Phys. 1968, 48, 715-726.

[24] R. Englman, J. Jortner, Mol. Phys. 1970, 18, 145-164.

[25] S. D. Cummings, R. Eisenberg, J. Am. Chem. Soc. 1996, 118, 1949 1960.

[26] P.-N. Lai, C. H. Brysacz, M. K. Alam, N. A. Ayoub, T. G. Gray, J. Bao, T. S. Teets, J. Am. Chem. Soc. 2018, 140, 10198-10207.

P.-N. Lai, T. S. Teets, Chem. - Eur. J. 2019, 25, 6026-6037.

J.-H. Shon, T. S. Teets, Inorg. Chem. 2017, 56, 15295-15303.

J.-H. Shon, S. Sittel, T. S. Teets, ACS Catal. 2019, 9, 8646-8658.

Y. Liu, K. Ye, Y. Fan, W. Song, Y. Wang, Z. Hou, Chem. Commun. 2009, 3699-3701.

[31] Z.-T. Yu, Y.-J. Yuan, J.-G. Cai, Z.-G. Zou, Chem. - Eur. J. 2013, 19, 1303-1310.

[32] V. K. Rai, M. Nishiura, M. Takimoto, Z. Hou, J. Mater. Chem. C 2014, 2, 5317-5326.

[33] R. A. Maya, A. Maity, T. S. Teets, Organometallics 2016, 35, 28902899.

[34] H.-C. Li, P.-T. Chou, Y.-H. Hu, Y.-M. Cheng, R.-S. Liu, Organometallics 2005, 24, 1329-1335.

[35] J. M. Fernandez-Hernandez, E. Longhi, R. Cysewski, F. Polo, H.-P. Josel, L. De Cola, Anal. Chem. 2016, 88, 4174-4178.

[36] C. You, D. Liu, F. Meng, Y. Wang, J. Yu, S. Wang, S. Su, W. Zhu, J. Mater. Chem. C 2019, 7, 10961-10971.

[37] H. U. Kim, H. J. Jang, W. Choi, M. Kim, S. Park, T. Park, J. Y. Lee, B. K. S., J. Mater. Chem. C 2019, 7, 4143-4154.

[38] A. J. Lees, Comments Inorg. Chem. 1995, 17, 319-346.

[39] A. B. Pangborn, M. A. Giardello, R. H. Grubbs, R. K. Rosen, F. J. Timmers, Organometallics 1996, 15, 1518-1520.

[40] M. Nonoyama, Bull. Chem. Soc. Jpn. 1974, 47, 767-768.

[41] I. El-Zoghbi, S. Latreche, F. Schaper, Organometallics 2010, 29, 1551-1559.

[42] P. G. Seybold, M. Gouterman, J. Mol. Spectrosc. 1969, 31, 1-13.

[43] G. M. Sheldrick, Acta Crystallogr. A 2008, 64, 112-122. 